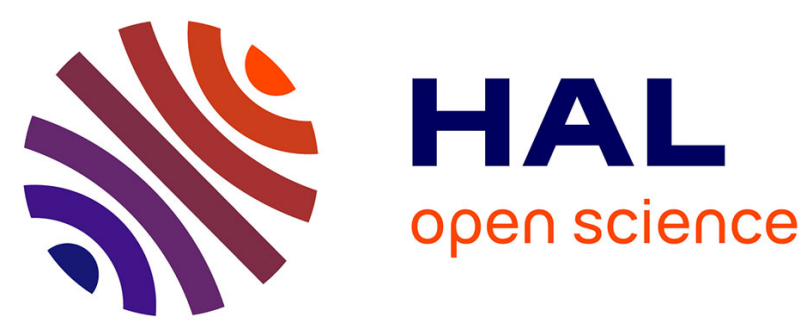

\title{
Deep particle stocks following the summer bloom around the Kerguelen islands: Insights into diatoms physiological state, community structure and mortality modes
}

Karine Leblanc, Augustin Lafond, Veronique Cornet, Justine Legras, Marie Barbara, B. Quéguiner, Karine Lafond, Barbara Marie

\section{To cite this version:}

Karine Leblanc, Augustin Lafond, Veronique Cornet, Justine Legras, Marie Barbara, et al.. Deep particle stocks following the summer bloom around the Kerguelen islands: Insights into diatoms physiological state, community structure and mortality modes. Journal of Marine Systems, 2021, 222, pp.103609. 10.1016/j.jmarsys.2021.103609 . hal-03450616

\section{HAL Id: hal-03450616 https://hal.science/hal-03450616}

Submitted on 26 Nov 2021

HAL is a multi-disciplinary open access archive for the deposit and dissemination of scientific research documents, whether they are published or not. The documents may come from teaching and research institutions in France or abroad, or from public or private research centers.
L'archive ouverte pluridisciplinaire HAL, est destinée au dépôt et à la diffusion de documents scientifiques de niveau recherche, publiés ou non, émanant des établissements d'enseignement et de recherche français ou étrangers, des laboratoires publics ou privés. 


\title{
Deep particle stocks following the summer bloom around the Kerguelen islands : insights into diatoms physiological state, community structure and mortality modes.
}

\author{
Leblanc $^{1 *}$ Karine, Lafond ${ }^{1}$ Augustin, Cornet ${ }^{1}$ Véronique, Legras ${ }^{1}$ Justine, Barbara \\ Marie $^{2}$, Quéguiner ${ }^{1}$ Bernard \\ ${ }^{1}$ Aix Marseille Univ., Université de Toulon, CNRS, IRD, MIO UM 110, 13288, Marseille, \\ France \\ 2 Sorbonne Université, CNRS, Laboratoire d'Océanographie Microbienne, LOMIC, F-66650, \\ Banyuls/mer, France.
}

*corresponding author : Karine Leblanc (karine.leblanc@univ-amu.fr)

\begin{abstract}
Particles located at the interface between the surface ocean layer and the top of the mesopelagic domain are the initial vector of the biological pump yet, their nature is still largely unknown. During the MOBYDICK cruise in the vicinity of the Kerguelen Islands (Indian sector of the Southern Ocean) we deployed a recently available device that allows to concentrate and collect deep particles over a predetermined layer of water. In this paper, we present the first detailed quantitative and qualitative data of the collected particles and individual planktonic cells, including their taxonomy, carbon and lipid content, as well as cell viability, in order to characterize the particle stocks present at depth. The cruise was carried out at the end of the summer bloom, a period characterized by declining stocks of biogenic materials associated with various mortality processes of planktonic organisms. Unexpectedly, the majority of the collected particles consisted of single empty diatom frustules, whereas fecal pellets and aggregates accounted for only a minor fraction. The occurrence of distinct mortality processes, from parasitic infection to mesozooplankton grazing, and of distinct silicification degrees as well as life-stages could be identified in relation to diatom taxa, evidencing distinct export modes to intermediate and deep layers within the diatom community.
\end{abstract}

\section{Keywords}

Biological carbon pump, diatoms, mortality modes, Southern Ocean, diversity, deep particle stocks

\section{Introduction}

The global carbon (C) export to the deep ocean is still poorly constrained and estimates range from 5 and $20 \mathrm{Pg} \mathrm{C} \mathrm{yr}^{-1}$ (Laws et al., 2000; Henson et al., 2011; Puigcorbé et al., 2020). Despite the overarching importance of this process in Earth climate regulation, the mechanisms responsible for the variability of carbon export are still largely unknown. Characterizing the composition of the particulate $C$ flux to depth together with the intricate ecological processes that can alter particle sinking rates are crucial in this context. Until now, the focus has been placed mainly on large $(>500 \mu \mathrm{m})$ 
aggregates and fecal pellets, otherwise known as marine snow, as primary vectors of $\mathrm{C}$ to the ocean's interior, mainly because of their elevated sinking rate, ranging from 5 to $2,700 \mathrm{~m} \mathrm{~d}^{-1}$ (Turner, 2002; Riley et al., 2012). Methodological challenges to accurately quantify the flux of diverse types of particles over the entire size-spectrum, from $\mu \mathrm{m}$ to $\mathrm{mm}$, have been identified already in the 80s (Alldredge and Silver, 1988) but are still difficult to overcome today, as no single instrument is able to characterize and quantify the entire particle size range together with its species-specific composition (Durkin et al., 2015). Recently, it has been suggested that in-situ aggregate size is not a sufficient descriptor for infering their sinking rates and that more information is needed on their excess density, age, composition and porosity (Iversen and Lampitt, 2020, Laurenceau-Cornec et al., 2020).

Furthermore, the taxonomic composition of phytoplankton, their biomineral content, and the physiological status of cells in the surface layer have been recognized as central in marine snow genesis (Alldredge and Gotschalk, 1990; Klaas and Archer, 2002, Laurenceau-Cornec et al., 2019). Until recently, the importance of single cells, and in particular small phytoplankton (Waite et al., 2000; Richardson and Jackson, 2007), was not recognized because their sinking rate was deemed too slow to lead to any significant contribution to $C$ export. Yet, recent studies report the presence of small particles under the form of single cells down to $1,000 \mathrm{~m}$ and deeper (Di Tullio et al., 2000; Dall'Olmo and Mork, 2014; Agusti et al., 2015, 2020; Durkin et al., 2016) revealing a potential important contribution of single cells to deep $\mathrm{C}$ stocks. The mechanisms invoked to explain these new observations are usually aggregation/disaggregation processes during descent in the water column, or entrainment through the mixed layer pump, in which deep mixing brings surface cells to depth rapidly, but such processes have not clearly been demonstrated (Gardner et al., 1995; Stemmann et al., 2004; Richardson and Jackson, 2007; Close et al., 2013; Giering et al., 2014; Durkin et al., 2015; Leblanc et al., 2018). A recent study carried out in the North Atlantic however estimated that eddy driven subduction could contribute to as much as $50 \%$ of total POC export (Omand et al., 2015). Only a few studies have reported the importance of whole diatom cells and spores in sinking $C$ flux (Kemp et al., 2000; Riaux-Gobin et al., 2006; Salter et al., 2007; Rembauville et al., 2015; Romero and Fischer, 2017), but the exact quantitative contribution of single cells to deep C stocks and fluxes remains unknown (Le Moigne, 2019), as direct C measurements associated to intact phytoplankton cells are time consuming and seldom undertaken (Assmy et al., 2013; Rembauville et al., 2015). It remains unclear whether this deep $C$ stock in the form of small individual cells plays a role in increasing the particulate $C$ flux either directly or through deep aggregation and/or repackaging processes (Lam and Marchal, 2015).

Similarly, fecal pellets are commonly examined in the large size fraction (at least $>50$ $\mu \mathrm{m})$ but the role of minipellets $(3-50 \mu \mathrm{m})$, as initially described by Gowing and Silver, (1985), has been overlooked. Minipellets can be produced by many different heterotrophs but are often linked to Phaeodaria, a group of siliceous Rhizaria (Gonzalez, 1992). Minipellets have been shown to represent a flux equivalent to 11$49 \%$ of the $C$ flux of larger fecal pellets in the Eastern Tropical Pacific Ocean (Gowing and Silver, 1985). This size-class of fecal pellets has been reported as extremely abundant in a series of field studies from the late 80 s and early 90 s conducted in the 
Eastern Tropical (Gowing and Silver, 1985) and North Pacific (Gowing, 1986), in the Atlantic (Riemann, 1989) as well as in the Southern Ocean along the Antarctic peninsula (Gonzalez, 1992). These types of particles have been ignored for more than 30 years in most biological $C$ pump studies, except for a temporal survey from the Northeast Atlantic, where high summer POC fluxes at $3000 \mathrm{~m}$ were shown to follow peaks in phaeodarian abundance (Lampitt et al., 2009). Recently, a renewed interest emerged with the recognized importance of Phaeodaria's role on both the Si and C cycle in the mesopelagic zone in the world ocean (Stukel et al., 2018; Biard et al., 2018). Another recent study in the North Pacific estimated that this group accounted for up to $10 \%$ of the total organic carbon of sinking particles (Ikenoue et al., 2019). Hence, marine snow and particles in the small size-range $(<50-100 \mu \mathrm{m})$ have until recently not been in the spotlight, for obvious methodological issues, and their relative contribution to deep $\mathrm{C}$ stocks and fluxes remains to be fully quantified in various oceanic regimes.

In 2015, a new device, called the Bottle net (Aquatic BioTechnology ${ }^{\mathrm{TM}}$ ) has allowed for methodological improvements in the collection of deep particle stocks. The device enables a rapid, detailed sampling of depth-integrated concentrated material collected over a very short time period (during a CTD upcast), allowing for taxonomical but also for physiological rate measurements since collection time is equal to that of Niskin samples (Agusti et al., 2015). Collection of particles between 2,000 and 4,000 m with this device during the Malaspina circumnavigation program in the subtropical oligotrophic ocean revealed the ubiquitous presence of fresh single cells in this deep layer. Diatoms, which do not dominate in surface oligotrophic waters, were surprisingly major contributors to microplankton cells at depth (81.5\%) and a large proportion (18\%) were intact viable cells, implying fast sinking rates estimated to $124-732 \mathrm{~m} \mathrm{~d}^{-1}$ (Agusti et al., 2015) comparable to aggregates and fecal pellets sinking rates. This device allows for a detailed analysis of small $(>20 \mu \mathrm{m})$ plankton cells and particles in microscopy, while sediment traps designed to measure downward fluxes do not adequately sample this small fraction, which is often merged in larger aggregates and phytodetritus within the collection cups and for which individual $\mathrm{C}$ content quantification is difficult. It is complementary to polyacrimide gel traps which also allow to study the contribution of individual cells and chains to the particulate flux (Laurenceau-Cornec et al., 2015).

A Bottle net was deployed during the MOBYDICK (Marine Ecosystem Biodiversity and Dynamics of Carbon around Kerguelen: an integrated view) cruise in the vicinity of the Kerguelen Islands in February-March 2018, a period coinciding with the demise of the recurrent summer bloom. The study region is considered as a natural fertilization laboratory (Blain et al., 2008), and several previous studies focused on the large phytoplankton bloom resulting from the island's Fe-enrichment of the plateau area by comparison to the the neighboring HNLC (High Nutrient Low Chlorophyll) region (Cornet-Barthaux et al., 2007; Mosseri et al., 2008; Armand et al., 2008a; Quéguiner, 2013; Lasbleiz et al., 2014; Lasbleiz et al., 2016). Here we compare results from phytoplankton nets (Phytonets) and Bottle net casts, while a companion paper describes in similar details the surface diatom communities from CTD Niskin collection (Lafond et al., 2020). We observed a dominant contribution of single cell diatoms (93 $\pm 6 \%$ ) to the deep particle stocks but a very small contribution of intact diatom cells 
$(\sim 0.3 \%)$ to $\mathrm{C}$ content in the intermediate layer $(125-500 \mathrm{~m})$, together with a very small fecal pellet contribution, that was dominated by the minipellet size-class. Taxonomical analyses revealed distinct communities west of Kerguelen in the HNLC area compared to the island's fertilized plateau and its eastern flank. Differences in silicification degrees as well as distinct mortality/export processes linked to surface nutrient depletion and trophic interactions (such as parasitic infection or grazing by phaeodarians) were identified in the upper layer, leading to distinct contributions of major diatom taxa to deep suspended particles.

\section{Material and methods}

\subsection{Study site}

The MOBYDICK cruise took place between February $18^{\text {th }}$ and March $27^{\text {th }}, 2018$ aboard the R/V Marion Dufresne south of the Kerguelen Islands (Southern Ocean). Four stations were investigated with repeated visits (Fig. 1, Table 1), including two so-called reference stations, M2 (sampled thrice) and M4 (sampled twice), corresponding respectively to the Fe-enriched plateau and the HNLC off-plateau area. To increase information on the spatial variability, two intermediate stations, M1 and M3 were additionally sampled, once and twice respectively. Bottom depths spanned from 520 $\mathrm{m}$ at M2 to 4,730 $\mathrm{m}$ at M4. According to Pauthenet et al. (2018), station M3 was located within the Polar Frontal zone at this time of the year, whereas the other stations were located in the POOZ (Permanently Open Ocean Zone) of the Antarctic zone, with M1 and M4 both situated very close to the Polar Front (Fig. 1).

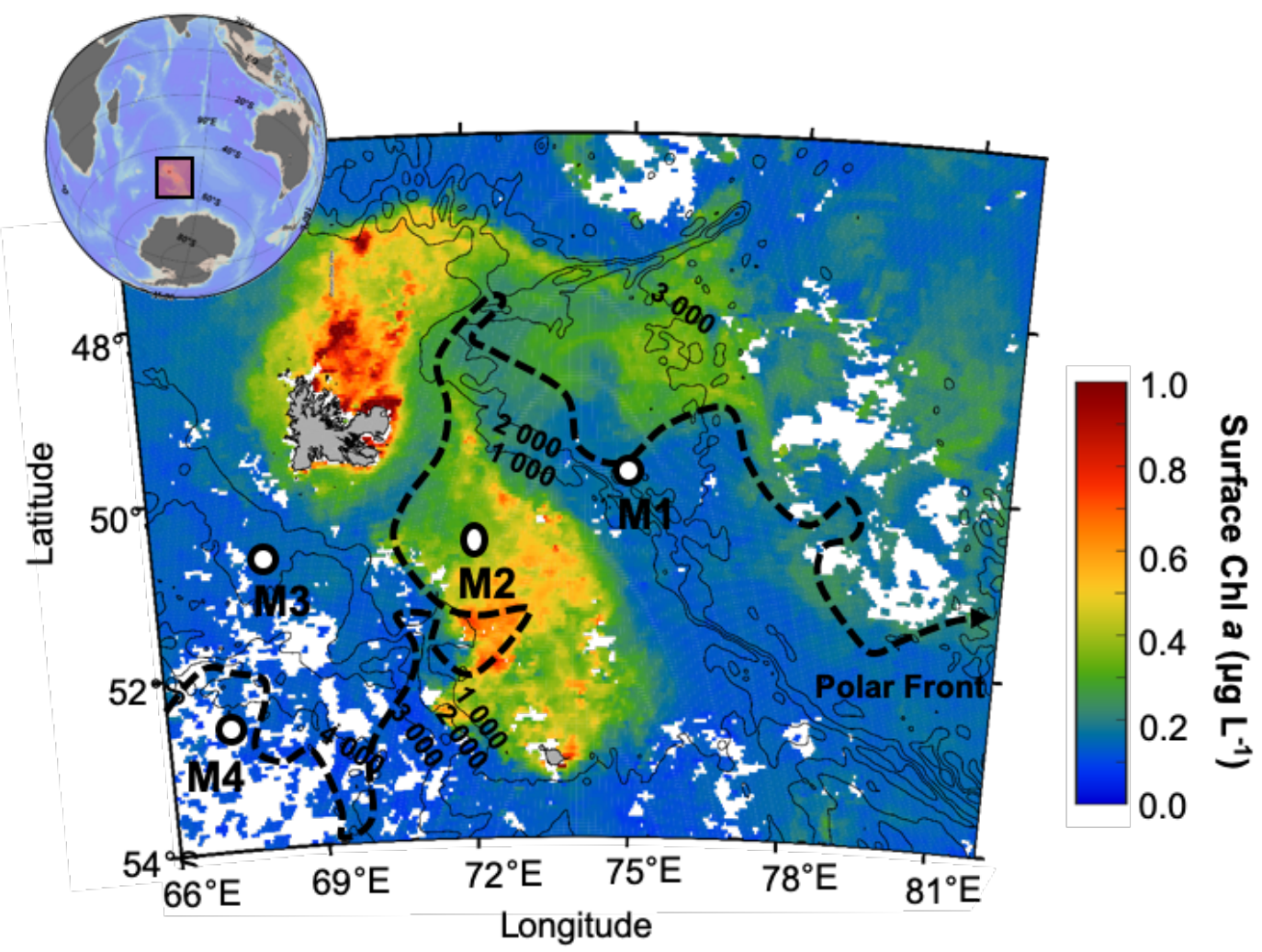


Figure 1: Station map of the four sampling sites around the Kerguelen Plateau, with surimposed satellite-Chl a map (monthly composite for March 2018).

Table 1: Metadata and hydrographical conditions at stations sampled during the MOBYDICK expedition.

\begin{tabular}{|c|c|c|c|c|c|c|}
\hline Station & Latitude/Longitude & Date & $\begin{array}{c}\text { Bottom } \\
\text { depth }(m)\end{array}$ & $\begin{array}{l}\text { MLD } \\
(\mathrm{m})\end{array}$ & $\begin{array}{c}\mathrm{Ze} 1 \% \\
\text { (m) }\end{array}$ & $\mathrm{H}_{4} \mathrm{SiO}_{4}: \mathrm{NO}_{3}{ }^{-}$ \\
\hline M1 & $49.85^{\circ} \mathrm{S} ; 74.90^{\circ} \mathrm{E}$ & $09 / 03 / 2018$ & 2723 & 63 & 89 & $0.27 \pm 0.01$ \\
\hline M2-1 & $50.62^{\circ} \mathrm{S} ; 72.00^{\circ} \mathrm{E}$ & $26 / 02 / 2018$ & 520 & 79 & 64 & $0.06 \pm 0.02$ \\
\hline M2-2 & & $06 / 03 / 2018$ & & 73 & 61 & $0.08 \pm 0.03$ \\
\hline M2-3 & & $16 / 03 / 2018$ & & 80 & 58 & $0.13 \pm 0.01$ \\
\hline M3-1 & $50.68^{\circ} \mathrm{S} ; 68.06^{\circ} \mathrm{E}$ & $04 / 03 / 2018$ & 1730 & 74 & 93 & $0.12 \pm 0.04$ \\
\hline M3-3 & & $19 / 03 / 2018$ & & 96 & 105 & $0.20 \pm 0.17$ \\
\hline M4-1 & 52 & $01 / 03 / 2018$ & 4731 & 69 & 95 & $0.17 \pm 0.01$ \\
\hline M4-2 & $02.005,01.20 \mathrm{~L}$ & $12 / 03 / 2018$ & וע 4 & 96 & 101 & $0.22 \pm 0.04$ \\
\hline
\end{tabular}

\subsection{Phytonet sampling}

A $35 \mu \mathrm{m}$ mesh phytoplankton net (hereafter called Phytonet) was deployed at all sites. Vertical net hauls were consistently realized between 0 and $125 \mathrm{~m}$ depth. Once on board, the net was gently rinsed from the outside using a hose connected to surface seawater. The window of the plankton collector was rinsed with a squirtbottle filled with $0.2 \mu \mathrm{m}$ filtered seawater to unclog all aggregates. The entire remaining volume (between $400-500 \mathrm{~mL}$ ) was immediately transferred to a polycarbonate bottle, which was then subsampled for diversity and cellular activity.

\subsection{Bottle net sampling}

A Bottle net (Aquatic Biotechnology ${ }^{\mathrm{TM}}$ ) was mounted on the rosette and deployed at each site. The device is a modified PVC bottle, holding a vertical $20 \mu \mathrm{m}$-plankton mesh and a plankton collector, that can be opened and closed between two chosen layers, to collect particles during the upcast (Agusti et al., 2015). Variable sampling depths were covered at each site and revisit depending on bottom bathymetry and CTDprofiles (Table 1, Fig. 2) for a total of 20 Bottle net casts. The intermediate layer (between approximately 125 and $500 \mathrm{~m}$ ) was sampled at least once at each site, together with deeper layers whenever possible. At station M4-2, two Bottle net casts (125-250 and 250-500 m) were combined for better comparison with the other stations. The Bottle net top opening is round-shaped and similar in size to a standard Niskin bottle $(7.5 \mathrm{~cm}$ diameter) and the amount of water filtered by the $20 \mu \mathrm{m}$ mesh varied between $0.1 \mathrm{~m}^{3}$ (for the 125-150 m cast) and $9.5 \mathrm{~m}^{3}$ (for the deep 1900-4000 m cast). Sampling with the CTD was performed at half speed $(0.5 \mathrm{~m} / \mathrm{s})$ during the Bottle net operations. Given the large body of water filtered, the total amount of particles and cells collected in approximately $50 \mathrm{~mL}$ of seawater varied between $26 \times 10^{6}$ and $28 \times 10^{7}$, thus allowing for a complete diversity analysis on concentrated material compared to Niskin bottles that contain only a very low average particle concentration in deep waters. 
Blanks. The design of the Bottle net unfortunately renders the closing lid vulnerable to lifting by the up and down pulling motion during the upcast if the rosette is stopped several times in the surface layer in order to close other Niskin bottles. In order to assess the contamination that might arise from plankton rich surface water seeping into the Bottle net during this stop-and-go ascent period, we carried out 5 blank casts ( 3 at $\mathrm{M} 2$ and 2 at $\mathrm{M} 3$ ), with the Bottle net closed during the entire cast. Blank samples were then counted for particles and compared to the average counts measured at both stations. At M2, the blank samples contained $8.7 \%$ of the average cell counts and was mostly comprised of Corethron inerme filaments which were accumulating in the surface layer, while at M3, blank casts represented $2.7 \%$ of the average cell counts. Despite this slight contamination from surface waters, we are confident that our subsequent analyses and comparison to surface communities allowed to filter out this signal and still give valid conclusions on the nature of deep particles and export-related processes.

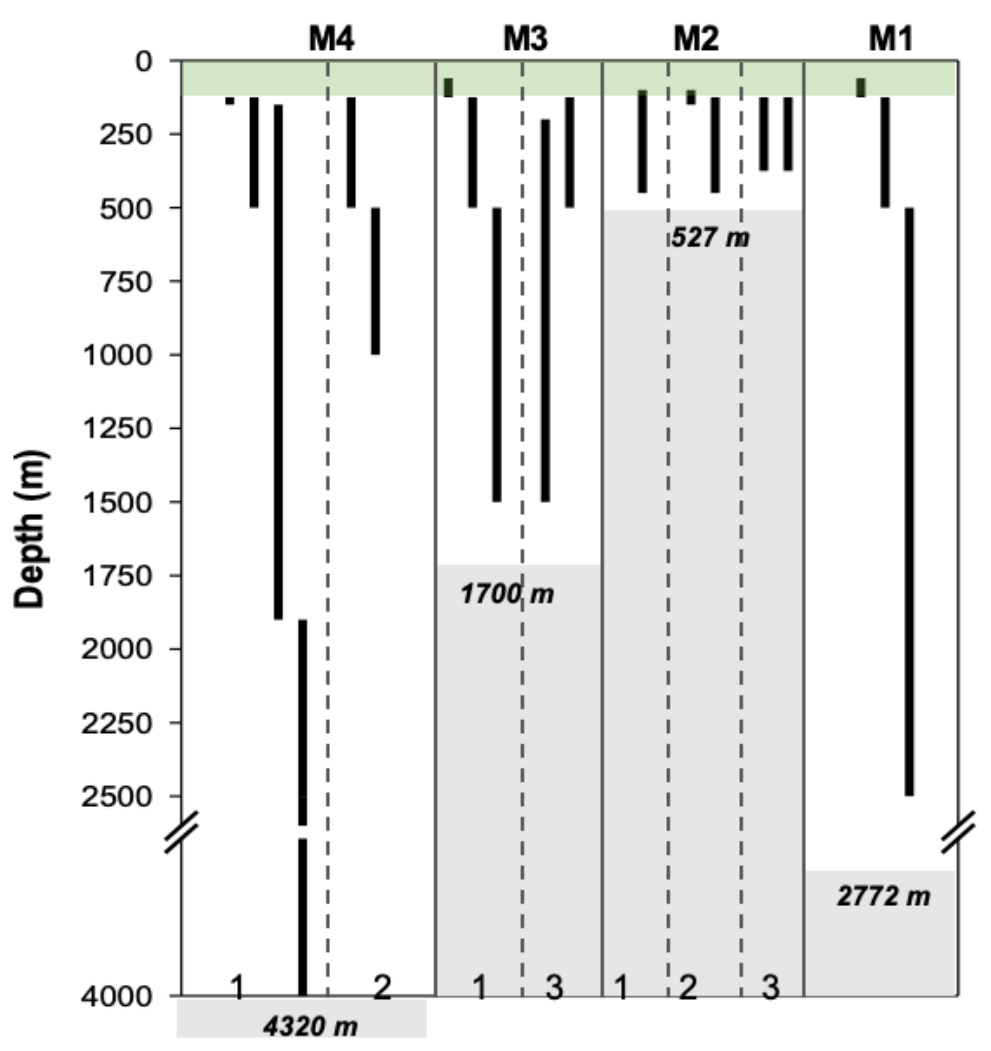

Figure 2: Bottle net casts depths at the 4 different sampling sites from West to East, and for the different revisits $(1,2,3)$. Bottom bathymetry is indicated in bold italic numbers. The green rectangle indicates the phytonet collection depth in the surface layer from 0 to $125 \mathrm{~m}$.

Collection. Samples were collected from the Bottle net on deck, after careful rinsing of its plankton net with a squirt bottle filled with $0.2 \mu \mathrm{m}$ filtered seawater. The collected volume varied between 48 and $70 \mathrm{~mL}$ of seawater. Each sample was transferred immediately into a polypropylene vial and very gently homogenized before several aliquots were subsampled for biogenic silica (BSi), microscopical identification, diatom viability and lipid content.

\subsection{Microscopical analyses}


2.4.1. Taxonomical identification and counting. Two samples for diversity were fixed with acidified lugol and $\mathrm{pH}$-buffered formol, while a third sample was filtered onto a 25 $\mathrm{mm} 0.2 \mu \mathrm{m}$ polycarbonate filter, rinsed with milliQ water then dried at room temperature, for Scanning Electron Microscopy (SEM) analyses. Upon sample collection from both the Bottle net and the Phytonet, a small aliquot was systematically observed on board within 30 min of collection using a bright-field Nikon TE-200 inverted microscope to observe any trophic behavior or parasitic activity. Further cell counts were later performed in the ground-based laboratory on a Nikon TE-200 inverted microscope, while detailed species identification has been carried out on a Phenom-Pro benchtop scanning electron microscope at $10 \mathrm{kV}$ using the untreated and uncoated dried filters. Species identification relied mostly on Priddle and Fryxell (1985) and Scott and Marchant (2005).

2.4.2. Mortality processes. In order to gain further insights into biological interactions and mortality processes in the diatom community, we carefully identified cell status: intact (e.g. cytoplasm still present and visually unaltered), empty (e.g. completely intact frustule with no cytoplasm visible), broken (e.g. with a clean break at the girdle band junction), crunched (e.g. frustule with a jagged break outside of the girdle junction, suppl. Fig. S1), or infected (e.g. frustule filled with small black cells, suppl. Fig. S2). While many mortality pathways can explain the presence of empty and broken frustules, crunched frustules are most likely due to handling by copepod or amphipod mandibles (Assmy et al., 2007). Infected cells were only observed at M2 and refer mainly to the infection of Corethron inerme (and to a lesser extent of Proboscia inerme and Rhizosolenia spp.). Life stages such as resting spores and resting cells (mainly of Odontella weissflogii), as well as different morphological/winter forms within some species (e.g. Chaetoceros atlanticus, Eucampia antarctica) were also identified and counted separately (suppl. Fig. S3).

2.4.3. Diatom viability. To further improve the physiological description of diatom cells, we used the SYTOX Green viability probe (Veldhuis et al., 2001) on all Phytonets samples and on 13 out of 20 Bottle net samples. Upon collection, $990 \mu \mathrm{L}$ of sample was placed in an Eppendorf PE $1.5 \mathrm{ml}$ vial and spiked with $10 \mu \mathrm{L}$ of $500 \mu \mathrm{L}$ SYTOX Green Nucleic Acid Stain (S7020, Life Technologies ${ }^{T M}$ ) $5 \mathrm{mM}$ solution, for a final concentration of $5 \mu \mathrm{M}$ and gently agitated. Samples were incubated for $30 \mathrm{~min}$ in the dark at in situ sampling temperature $\left(4^{\circ} \mathrm{C}\right)$, then transferred onto a Sedgewick Rafter graduated $1 \mathrm{~mL}$ chamber and immediately counted on board on a Zeiss imager A2 epifluorescence microscope, using an FITC filter cube ( $\lambda$ ex: $479 / 39 \mathrm{~nm}$, $\lambda$ em: 522/40 $\mathrm{nm}, 497 \mathrm{~nm}$ LP). Non-viable cells, which have lost membrane integrity, incorporate the probe and their nuclei display a green fluorescence, while viable cells with intact membranes only show chlorophyll a ( $\mathrm{Chl} \mathrm{a)}$ red autofluorescence.

2.4.4. Lipid content. The presence of lipids inside diatom cells was assessed using Nile Red labelling (Greenspan, 1985). Seawater samples were treated on board immediately after collection. Cells were resuspended in $1 \mathrm{ml} \mathrm{HEPES}$ buffer $0.1 \mathrm{M}(\mathrm{pH}$ 7) containing $2 \%$ glutaraldehyde, $10 \mathrm{mM} \mathrm{CaCl}_{2}$ and $10 \mathrm{mM} \mathrm{MgCl}_{2}$. After $1 \mathrm{~h}$ incubation at $4^{\circ} \mathrm{C}$ and in the dark, samples were again centrifuged, rinsed and resuspended in 1 $\mathrm{ml} \mathrm{HEPES}$ buffer $0.1 \mathrm{M}$. Samples were stored at $4^{\circ} \mathrm{C}$ until analyses at the laboratory. Nile Red was added to each sample at a final concentration of $5 \mu \mathrm{g} / \mathrm{mL}$ sample, 
vortexed for $20 \mathrm{~s}$ and incubated $5 \mathrm{~min}$ at room temperature. The sample was then mounted onto a glass slide and observed on a Zeiss Observer Z1 epifluorescence inverted microscope using a DS Red filter cube ( $\lambda$ ex: $550 / 25 \mathrm{~nm}$; beamsplitter $570 \mathrm{~nm}$ LP, $\lambda$ em: $605 / 70 \mathrm{~nm}$ ). The percentage of each diatom taxon in the Bottle net samples containing lipid droplets was then determined by scanning a counting a graduated Sedgewick Rafter chamber.

\subsubsection{Spore induction and germination experiments}

At station M2, a larger amounts of resting spores and winter forms were observed for several taxa such as Odontella weissflogii, Chaetoceros atlanticus, Eucampia antarctica and Proboscia inerme, coinciding with a higher Si-limitation at this site with low Si/DIN (Dissolved Inorganic Nitrogen) surface ratios $(0.05-0.11)$. Hence, this site was chosen for exploratory experiments on resting spore induction and germination processes. At the first visit (M2-1), a spore induction experiment was carried out using $6 \times 500 \mu \mathrm{L}$ aliquots collected from the 100-450 m Bottle net sample. All aliquots were resuspended in $15 \mathrm{~mL}$ low nutrient water (collected at $30^{\circ} \mathrm{S}$ during transit to the study area) and three were placed in a dark incubator (low nutrient dark treatment) while the three other were placed in a lit incubator (50\% of incoming surface light) cooled with running surface water. After 20 days, samples were fixed with acidified lugol and stored at $4^{\circ} \mathrm{C}$. Resting spores and winter stages were enumerated back at the laboratory in all samples in an Utermöhl sedimentation cuve.

On the second visit at this site (M2-2), a spore germination experiment was conducted on the most frequently observed resting spores (Odontella weissflogii). Two times 15 resting cells of $O$. weissflogii were isolated under the microscope onboard from the 100-150 m Bottle net samples and resuspended in $10 \mathrm{~mL}$ filtered low nutrient water collected underway at $30^{\circ} \mathrm{S}$. Both samples were placed in a lit surface incubator with no nutrient addition for the light treatment and $+20 \mu \mathrm{M} \mathrm{Si}$ and $+1 \mu \mathrm{M} P$ for the light+nutrient treatment. After 12 days of incubation, samples were fixed with acidified lugol and stored at $4^{\circ} \mathrm{C}$. Resting spores and vegetative cells were enumerated back at the ground-based laboratory in all samples in an Utermöhl sedimentation cuve.

\subsection{Biogenic Silica (BSi)}

An aliquot of $10 \mathrm{~mL}$ was filtered for biogenic silica (BSi) onto a $47 \mathrm{~mm} 0.6 \mu \mathrm{m}$ polycarbonate filter, which was rinsed with milliQ water and dried at $60{ }^{\circ} \mathrm{C}$ for $24 \mathrm{~h}$. Analyses were carried out in the laboratory following the triple $\mathrm{NaOH} / \mathrm{HF}$ extraction procedure (Ragueneau et al., 2005). This method allows to correct for possible BSi overestimation due to the dissolution of siliceous lithogenic material during the first leaching. Blank values, estimated from measurement of 8 independent samples were $19.3 \pm 14.2 \mathrm{nmol} \mathrm{L}^{-1}$ for biogenic silica, $13.3 \pm 1.6 \mathrm{nmol} \mathrm{L}^{-1}$ for lithogenic silica, and 1.7 $\pm 1.0 \mathrm{nmol} \mathrm{L}^{-1}$ for particulate aluminum.

\subsection{Carbon content calculations}

Carbon content was calculated for diatoms in all Bottle net samples based on intact and broken cells with visible cytoplasmic content, after size and shape measurements in light microscopy (following NF EN 166195, 2015). The carbon conversion formula 
304 from biovolume (in $\mu \mathrm{m}^{3}$ ) was derived from Eppley et al. (1970) modified by Smayda, 305 (1978): 


\section{Results}

\subsection{Caracterization of deep particle stocks}

Integrated and absolute particle abundances are presented in Fig. 3 and Table 2 respectively. Within the intermediate layer (i.e. 125-500 m), M1 exhibited the lowest particle (part.) abundances $\left(3.1 \times 10^{7}\right.$ part. $\left.\mathrm{m}^{-2}\right)$ while the HNLC station M4 exhibited the highest abundances $\left(2.6 \times 10^{8}\right.$ part. $\left.\mathrm{m}^{-2}\right)$. In this intermediate layer, abundances decreased at all sites between the first and last visits which occurred 11 to 15 days later, paralleling the demise of the bloom. The intermediate layer at the plateau station M2 could only be sampled between $100-450 \mathrm{~m}$ ( $1^{\text {st }}$ visit $), 125-450 \mathrm{~m}$ ( $2^{\text {nd }}$ visit $)$ and $125-$ $375 \mathrm{~m}$ ( $3^{\text {rd }}$ visit) which renders the comparison with the other stations more difficult. Nevertheless, according to the 125-450 m layer sampled during the second visit, we can fairly assume that particle abundances were intermediate $\left(1.1 \times 10^{8}\right.$ part. $\left.\mathrm{m}^{-2}\right)$, being higher than $\mathrm{M} 1$ but lower than M3/M4. When expressed in number of particles per cubic meter (Table 2), we observe a clear decreasing trend with depth at all stations, except at M3-1 where particle concentrations were higher within the 125-500 $\mathrm{m}$ layer $\left(6.1 \times 10^{5}\right.$ part. $\left.\mathrm{m}^{-3}\right)$ compared to the $60-125 \mathrm{~m}$ layer $\left(4.0 \times 10^{5}\right.$ part. $\left.\mathrm{m}^{-3}\right)$. In the deep layers (i.e. $>500 \mathrm{~m}$ ), particle concentrations ranged between $5.0 \times 10^{4}$ part. $\mathrm{m}^{-3}$ at $\mathrm{M} 1$ to $1.9 \times 10^{5}$ part. $\mathrm{m}^{-3}$ at $\mathrm{M} 4-2$.

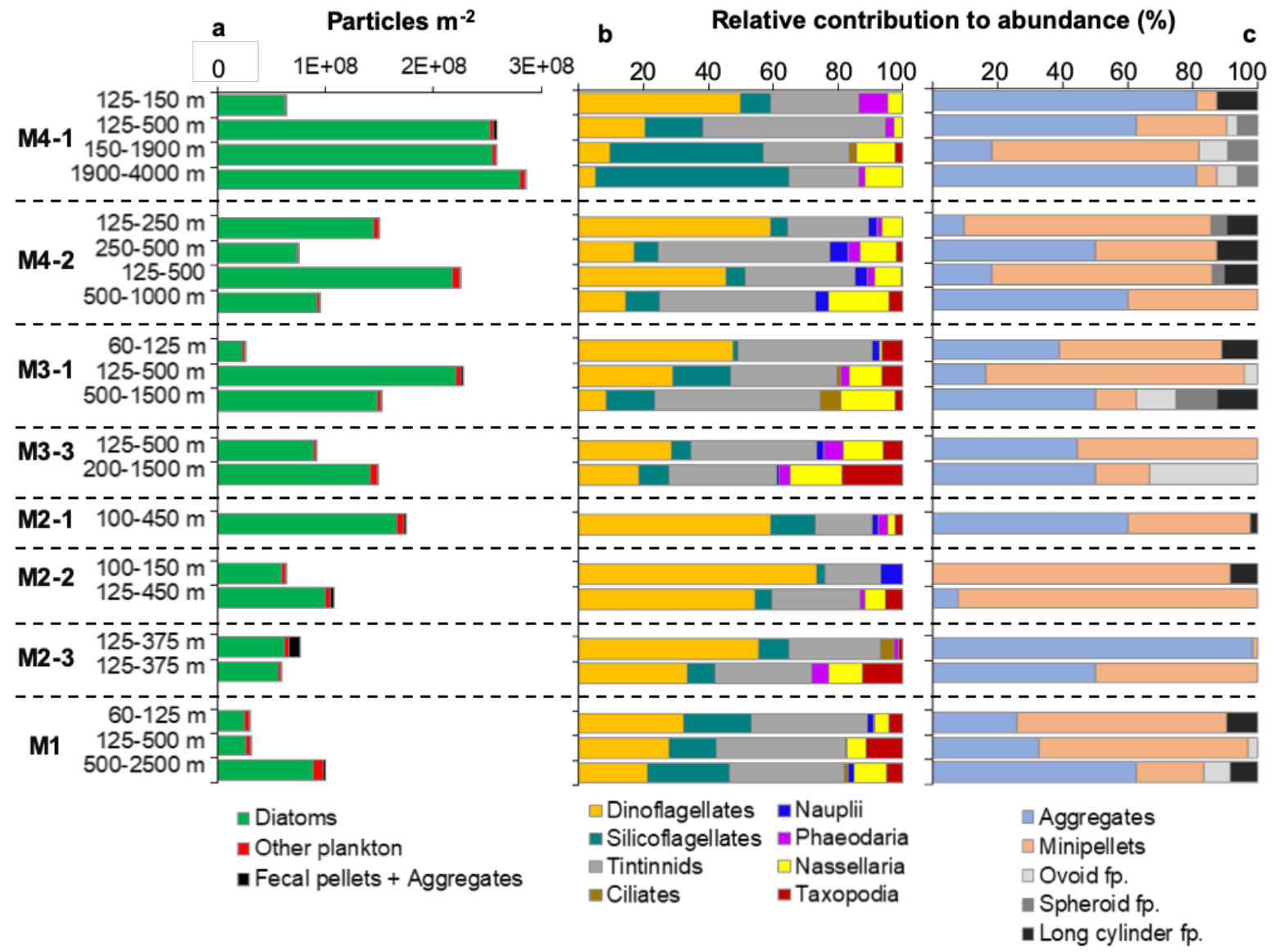

Figure 3: a. Integrated particles per $\mathrm{m}^{-2}$ for diatoms, other microplankton and fecal pellets+aggregated for all Bottle net casts at the four study sites. The integration depth is indicated on the left axis. b. Relative percent contribution of main lineages to the other microplankton groups (excluding diatoms) in all Bottle net. c. Relative percent contribution of different types of inert particles : aggregates, minipellets $<50 \mu \mathrm{m}$, and three different types of fecal pellets (fp.). 
Table 2 : Particle concentration (total cells + aggregates + fecal pellets) in particles $\mathrm{m}^{-3}$ for all Bottle net samples according to station and sampling interval.

\begin{tabular}{|c|c|c|}
\hline Station & $\begin{array}{l}\text { Integrated } \\
\text { sampling } \\
\text { depth (m) }\end{array}$ & $\begin{array}{c}\text { Particle } \\
\text { concentration } \\
\text { (particle } \mathrm{m}^{-3} \text { ) }\end{array}$ \\
\hline \multirow{3}{*}{ M1 } & $60-125 \mathrm{~m}$ & 468032 \\
\hline & $125-500 \mathrm{~m}$ & 83680 \\
\hline & $500-2500 \mathrm{~m}$ & 49826 \\
\hline M2-1 & $100-450 \mathrm{~m}$ & 499935 \\
\hline M2-2 & $\begin{array}{l}100-150 \mathrm{~m} \\
125-450 \mathrm{~m}\end{array}$ & $\begin{array}{c}1267622 \\
331988\end{array}$ \\
\hline \multirow{2}{*}{ M2-3 } & $125-375 \mathrm{~m}$ & 307361 \\
\hline & $125-375 \mathrm{~m}$ & 236546 \\
\hline \multirow{3}{*}{ M3-1 } & $60-125 \mathrm{~m}$ & 398300 \\
\hline & $125-500 \mathrm{~m}$ & 606904 \\
\hline & $500-1500 \mathrm{~m}$ & 151480 \\
\hline \multirow{2}{*}{ M3-3 } & $125-500 \mathrm{~m}$ & 245226 \\
\hline & $200-1500 \mathrm{~m}$ & 113800 \\
\hline \multirow{4}{*}{ M4-1 } & $125-150 \mathrm{~m}$ & 2523000 \\
\hline & $125-500 \mathrm{~m}$ & 689680 \\
\hline & $150-1900 \mathrm{~m}$ & 148016 \\
\hline & $1900-4000 \mathrm{~m}$ & 135767 \\
\hline \multirow{2}{*}{ M4-2 } & $125-500 \mathrm{~m}$ & 600736 \\
\hline & $500-1000 \mathrm{~m}$ & 189719 \\
\hline
\end{tabular}

Regarding the type of particles collected, one of the most striking features was the dominance of diatom cells at all sites and depths (Fig. 3a). On average, diatom cells represented $93 \pm 6 \%(n=19)$ of the total particle amount, while other microplankton groups only represented $5 \pm 4 \%$. Surprisingly, particles such as fecal pellets and aggregates only contributed to $2 \pm 3 \%$ of the total particle amount. The relative abundance of microplankton other than diatoms was the highest at $\mathrm{M} 1$ reaching up to $16 \%$ of the total particle amount within the 60-125 m layer. Aggregates, mostly largesized $(100-400 \mu \mathrm{m})$ were the most numerous at M2-3 (125-375 m layer) contributing to $14 \%\left(1.0 \times 10^{7}\right.$ part. $\left.\mathrm{m}^{-2}\right)$ of the total particle amount while they did not exceed $1 \%$ at the other stations. Interestingly, those large aggregates were not observed within the same layer sampled $8 \mathrm{~h}$ later, suggesting a short-lived export event.

Among identified microplankton groups, excluding diatoms (Fig. 3b), tintinnids (35 \pm $12 \%)$ and dinoflagellates (34 $\pm 21 \%$ ) were dominant at most sites and depths. Silicoflagellates was the following most abundant group $(16 \pm 15 \%)$. They were notably found to increase with depth, and were the highest for the two deepest casts at M4-1 (48 \% at 150-1900 m, $60 \%$ at 1900-4000 m) and at M1 (26\% at 500-2500 m). Siliceous Rhizaria was the next most abundant group with a large diversity of species belonging to different lineages (e.g. mainly Nassellaria, Phaeodaria, and Taxopodia). Nassellaria were present at all stations $(8 \pm 6 \%)$ with the most abundant species belonging to the Theoperidae, Plagoniidae and Artostrobiidae groups. A rarely mentioned Taxopodia, which only has one described species (Sticholonche zanclea) was also very frequent at all sites and depths ( $5 \pm 5 \%)$. Phaeodarians were also often present though in minor proportions $(2 \pm 2 \%)$ and were mostly represented by several Protocystis species (e.g. P. tridens, P. swirei, P. balfouri, P. harstoni, P. micropelecus). Although minor contributors to the deep water particle stocks, they should play an important role in the production of minipellets (Fig. 3c, Fig. 4a). 
Among inert particles (Fig. 3c), identifiable fecal pellets (round, ovoid or elongated) were negligible ( $10 \%$ on average for all casts) compared to aggregates and minipellets which both constituted $45 \%$ on average of the remaining particles (see suppl. Fig. S4 for pictures of different types of particles). Minipellets are typically $<50 \mu \mathrm{m}$ wide and are known to be excreted by the Protocystis genus (Phaeodaria) (Gonzalez, 1992) that was very abundant in surface Phytonets (data not shown). The occurrence of Phaeodaria and their trophic behavior will be further discussed in another paper (Leblanc et al., in prep). Here, minipellets were mostly constituted of diatom fragments, mostly belonging to the species Fragilariopsis kerguelensis (Fig. 4a, suppl. Fig. S4b), while Protocystis spp. were repeatedly observed in the Phytonet samples with one or several whole ingested $F$. kerguelensis cells. Small aggregates $(<100 \mu \mathrm{m})$ were the most dominant type of aggregates and were also tightly packed with crushed diatom debris, as well as coccoliths (Emiliania huxleyi) in some samples. Fecal pellets imaged by SEM revealed a very high content in biominerals, mostly diatom frustule debris (Fig. 4). 

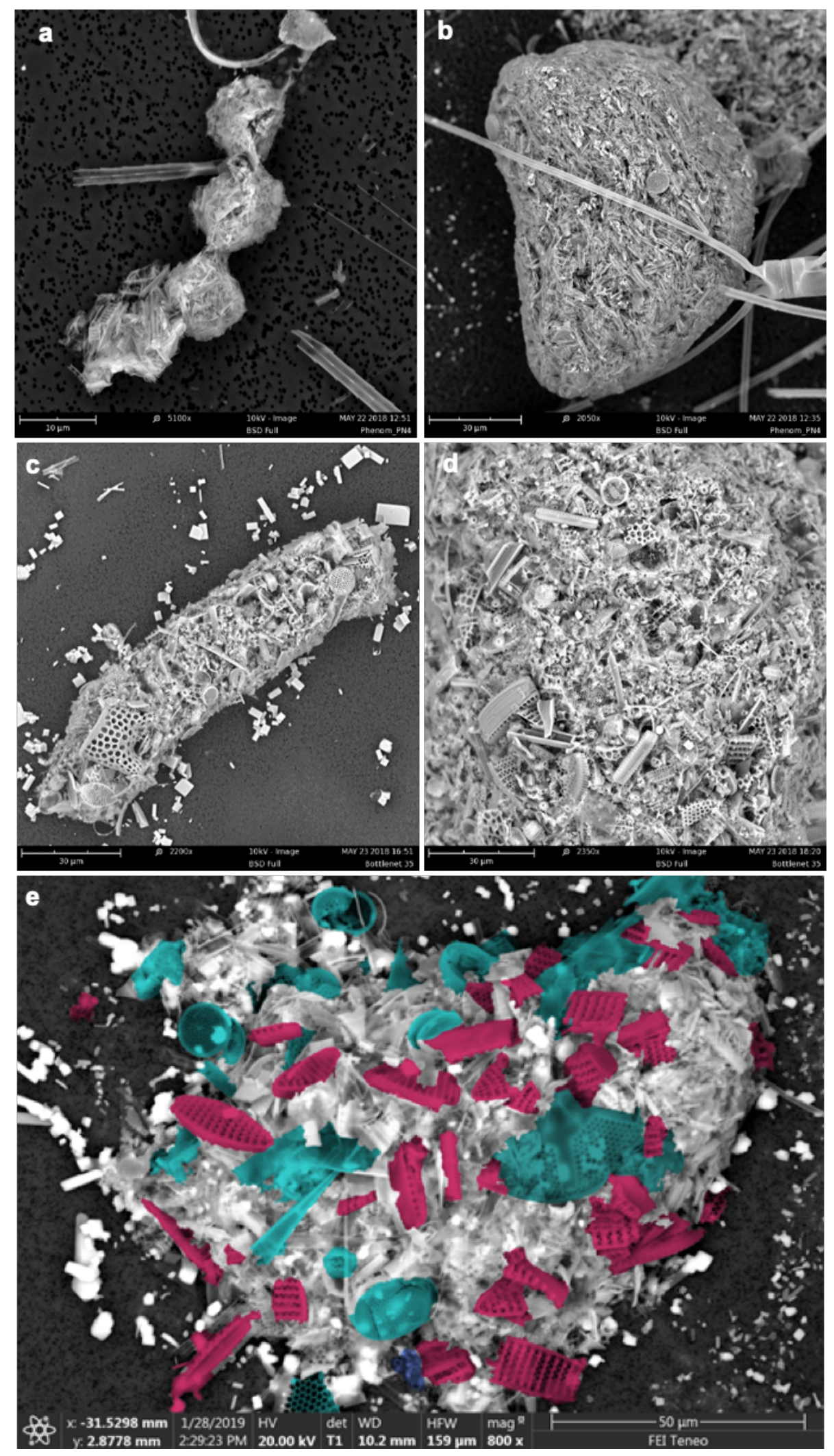

Figure 4: a. Phaeodarian minipellets, b. ovoid fecal pellet, c. long fecal pellet, $d$. zoom on a round fecal pellet content. e. Loose fecal pellet containing recognizable debris of Fragilariopsis kerguelensis (pink) and centric diatoms (turquoise). A few coccoliths are also visible (purple). 


\subsection{Diatom physiological state}

The state of the diatom cells within the upper 0-125 m layer sampled by the Phytonet and the deeper layers sampled by the Bottle net is presented in Fig. 5. Within the upper 0-125 m layer, diatoms were mostly intact (62 $\pm 12 \%)$, while the remaining frustules were broken $(24 \pm 11 \%)$ or empty $(9 \pm 6 \%)$. No large differences were observed between stations, except at M4-1 where more broken frustules were observed (43\%). At the reference plateau station $\mathrm{M} 2$, a parasitic infection event was observed at the three visits, affecting almost exclusively the species Corethron inerme and to some lesser degree Proboscia and Rhizosolenia. The percentage of infected frustules varied between $14 \%\left(1^{\text {st }}\right.$ visit) to $9 \%$ ( $3^{\text {rd }}$ visit) within the upper layer. At depth, infected cells were only observed at the last visit (i.e. M2-3, $21 \%$ of the cells) within the 125-375 m layer. Interestingly, those infected cells were associated with large aggregates and were not found in the following cast performed 8 hours later.

In Bottle net samples, the most conspicuous feature was the decreasing contribution of intact cells with depth, at all stations and visits. Within the intermediate layer (125$500 \mathrm{~m})$, frustules were mostly empty $(49 \pm 5 \%)$ or broken $(26 \pm 6 \%)$, while intact cells were a minority $(23 \pm 8 \%)$. In the deep layers located below $500 \mathrm{~m}$, only few intact cells were still observed, contributing to $5 \pm 1 \%$ of the total cells. Crunched frustules indicative of mesozooplankton grazing were rare in most samples $(<3 \%)$, although they were more frequent at $M 1$, with a contribution of 5-6\% within the $60-2500 \mathrm{~m}$ layer.

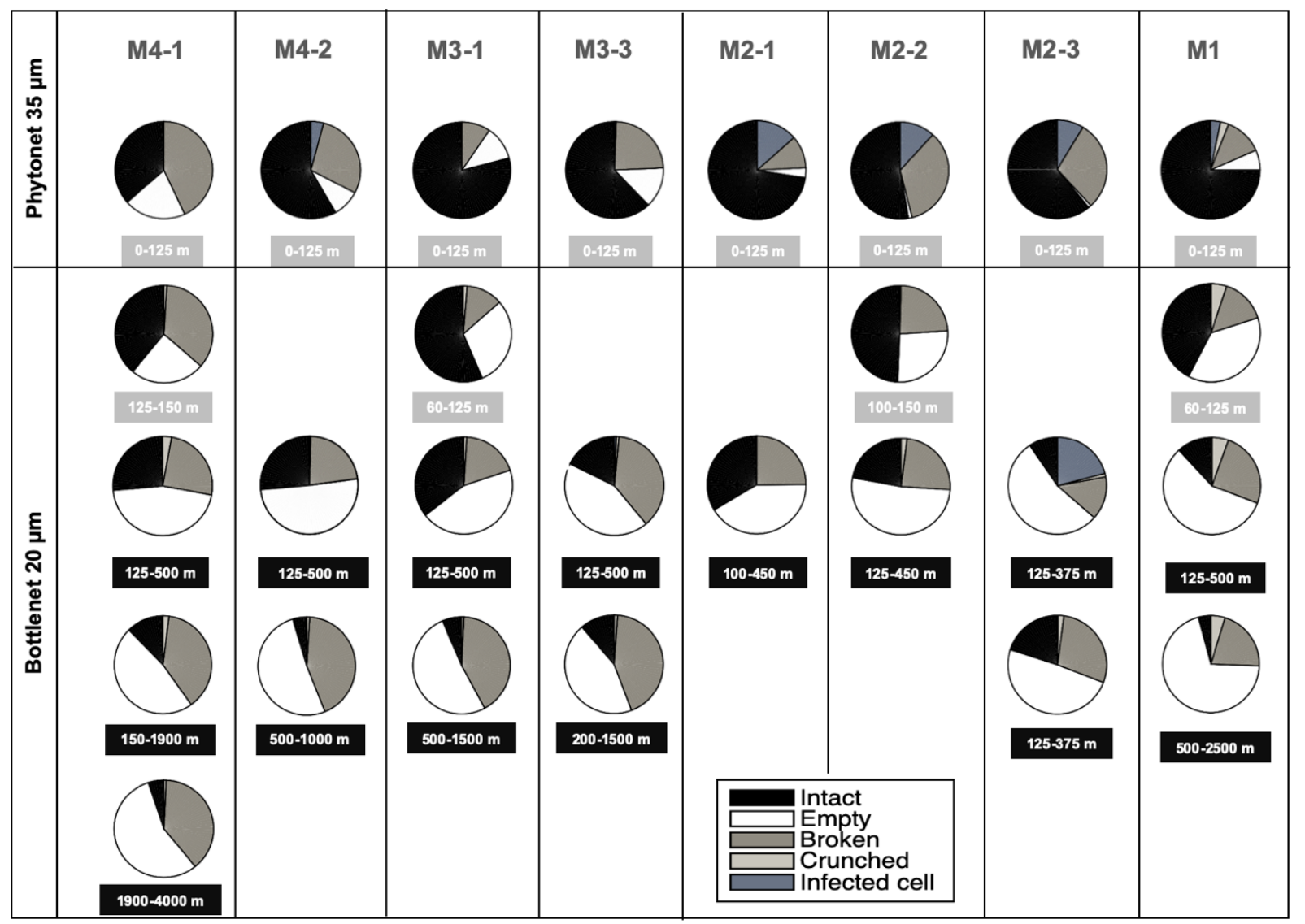

Figure 5 : Observed state of diatom cells in the Phytonet samples (upper pannel) and in the Bottle net samples (lower pannel) at each site and revisit. Collection depth is indicated below each pie chart. See method section for "crunched" and "infected" definition. 
Viability test

Results from the SYTOX Green labelling experiment showing the percentage of viable cells quantified on board immediately after sampling are presented in Table 3 . The percentage of viable diatom cells decreased at all sites between revisits, in both Phytonets and Bottle nets. Within the upper 0-125 m layer, the percentage of viable diatoms was the highest at station M3 (64\% then 47\%) indicating a good physiological state of the cells, while it was the lowest at the eastern station M1 (18\%) and above the plateau at $\mathrm{M} 2$, where a decreasing trend from $47 \%$ ( $^{\text {st }}$ visit) to only $6 \%$ ( $^{\text {rd }}$ visit) highlights the decaying stage of the diatom population, even though visually intact cells represented a much larger contribution (Fig. 5). In the intermediate layer at M2, viable diatoms in the Bottle nets closely followed that of the Phytonets $(43,25$ and $8 \%)$. At the HNLC station M4, viable diatoms represented only a small third of total cells $(28 \%$ then $26 \%$ ). A larger proportion of live cells (64\%) was found in a subsurface layer (125$150 \mathrm{~m}$ ) at station M4-1, and this proportion was still fairly elevated in the deeper casts upon the first visit, with 29 and $24 \%$ of viable cells in the 150-1900 and 1900-4000 m casts respectively. On the second visit however; this proportion dropped substantially, with only $4 \%$ viable cells between 250-500 m and none in the 500-1000 m layer, also suggesting the decay of the diatom population.

Table 3: Percentage live diatom cells within total diatom cells counted after SYTOX labelling at each site, revisit and integrated sampling depth for the surface phytonet samples and for Bottle net casts.

\begin{tabular}{ccc}
\hline Station & $\begin{array}{c}\text { Integrated } \\
\text { sampling } \\
\text { depth }(\mathbf{m})\end{array}$ & $\begin{array}{c}\text { \% live } \\
\text { diatoms }\end{array}$ \\
\hline \multirow{3}{*}{ M1 } & $0-125$ & 18 \\
& $125-500$ & 11 \\
& $500-2500$ & 1 \\
\hline \multirow{2}{*}{ M2-1 } & $0-125$ & 47 \\
& $100-450$ & 43 \\
\hline \multirow{2}{*}{ M2-2 } & $0-125$ & 19 \\
& $125-450$ & 25 \\
M2-3 & $0-125$ & 6 \\
& $125-375$ & 8 \\
\hline \multirow{2}{*}{ M3-1 } & $0-125$ & 64 \\
& $125-500$ & 20 \\
\hline \multirow{2}{*}{ M3-2 } & $0-125$ & 47 \\
& $125-500$ & 12 \\
\hline & $0-125$ & 28 \\
& $125-150$ & 64 \\
M4-1 & $125-500$ & 51 \\
& $150-1900$ & 29 \\
& $1900-4000$ & 24 \\
\hline \multirow{3}{*}{ M4-2 } & $0-125$ & 26 \\
& $250-500$ & 4 \\
& $500-1000$ & 0 \\
\hline
\end{tabular}

\subsection{Diatom community structure within surface and deep layers}

\section{Relative abundances}

Diatom relative abundances from samples collected by both the Phytonet and the Bottle net are presented in Fig. 6. Results show a clear difference in diatom communities between the two stations located above the plateau (M2) and east of 
the upper $125 \mathrm{~m}$ layer, the Fe-fertilized plateau was dominated by Corethron inerme $(81 \pm 12 \%)$ and Proboscia spp. (mostly P. alata; $9 \pm 3 \%$ ). At M2, the Phytonet contents closely matched the surface layer niskin observations (Lafond et al., 2020) showing increasing abundances at each revisit of extremely long Corethron inerme filaments (up to $7-8 \mathrm{~mm}$ long, up to 74 cells in one filament) in the mixed layer ( $~ 80 \mathrm{~m})$. At M1, some Corethron cells (13\%) were again observed in the surface Phytonet, but this genus was not dominant, while Fragilariopsis kerguelensis (42\%) and centric species constituted the bulk of diatom diversity.

In the intermediate layer $(125-500 \mathrm{~m})$ at $\mathrm{M} 2$ and $\mathrm{M} 1$, the Bottle net samples reflected a very similar community, that was dominated by a mix of Eucampia antarctica (30 \pm $23 \%)$, F. kerguelensis (26 $\pm 16 \%$ ), and Corethron spp. $(19 \pm 7 \%)$, although the importance of $E$. antarctica declined throughout the survey period, while the contribution of $C$. inerme increased with time at M2. Species belonging to the genus Pseudo-nitzschia (mostly P. heimii) were also present contributing up to $18 \%$ of the abundances at the last visit (125-375 m layer) and up to $25 \%$ in the deeper cast at M1 (500-2500 m). These results suggest that M1 was partly influenced by the nearby plateau despite its higher bathymetry which is coherent with the water mass circulation (Park et al., 2014).

By contrast, the surface layer of the western stations M3/M4 was dominated at the first visits by Chaetoceros atlanticus (64 $\pm 12 \%)$, progressively replaced by a mix of different taxa at the second visit: Chaetoceros atlanticus (20 $\pm 11 \%)$, other centrics (14 $\pm 9 \%$; mainly unidentified centrics), Actinocyclus/Thalassiosira spp. (13 $\pm 16 \%)$, Dactyliosolen antarctica $(9 \pm 4 \%)$, Proboscia spp. (9 $\pm 1 \%)$, Rhizosolenia spp. (9 \pm 1 $\%)$, and Corethron spp. ( $8 \pm 4 \%)$. Diatom communities were much less diverse within the intermediate and deep layers and largely dominated by Chaetoceros atlanticus (71 $\pm 11 \%$ ), followed by $F$. kerguelensis (11 $\pm 5 \%$ ). Other Chaetoceros spp., mostly $C$. dichaeta were also non negligible contributors to abundances at M4 (8 $\pm 2 \%$ at both visits).

\section{Winter stages and resting spores}

The heavily silicified Chaetoceros atlanticus was a key species at the western stations M3/M4. It occurred under several forms: long chains composed of vegetative cells, a solitary stage with sigmoidal setae, which is likely a resting cell form, and under the 'bulbosum' form, which is thought to be the resting spore stage for this species (suppl. Fig. S3). In the surface layer, the vegetative stage was dominant at M4/M3/M1 but the solitary sigmoidal stage was also present even though less abundant. Interestingly, the 'bulbosum' stage was never observed in the Phytonets but was abundant in the subsurface Bottle net samples at M4-1 (125-150 m), M4-2 (125-250 m), M3 (65-125 $\mathrm{m})$ and M1 (65-125 m), suggesting a sporulation event occurring below the mixed layer, although we cannot exclude that the 'bulbosum' form was not retained by the 35 $\mu \mathrm{m}$ mesh size of the Phytonet. The 'bulbosum' stage was also present albeit at lower abundances in almost all the deepest Bottle net casts. 


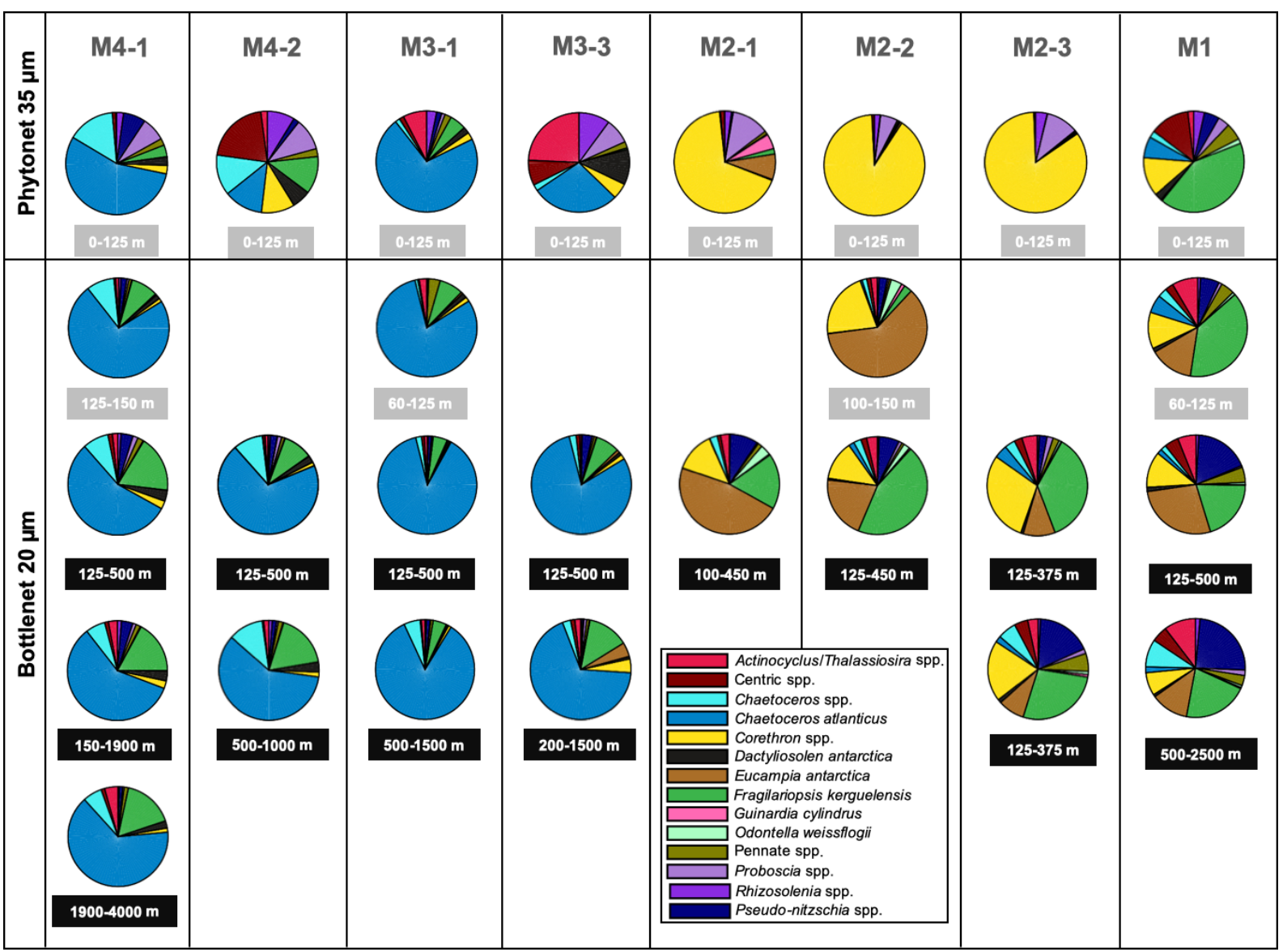

Figure 6: Relative contribution of diatom cells main taxa to abundance (comprising both intact and empty cells) in the Phytonet samples (upper pannel) and in the Bottle net samples (lower pannel) at each site and revisit. Collection depth is indicated below each pie chart.

Winter stages of another heavily silicified species Eucampia antarctica (suppl. Fig. S3), as small rectangular forms (Fryxell and Prasad, 1990), were quasi absent from the Phytonet samples, which could also be due to the mesh size exceeding their average size $(15-30 \mu \mathrm{m})$, but were on the other hand very abundant in the subsurface casts starting below $100 \mathrm{~m}$ at $\mathrm{M} 2$ and $\mathrm{M} 1$ in the Bottle net samples. This small winter form was minor at M3 and quasi absent at M4.

Several Odontella weissflogii morphotypes were also observed during the cruise. The vegetative lightly silicified stage was quasi absent from all samples, while a rectangular form, much more silicified than the vegetative stage and with short apical horns was the dominant form. This stage has been termed as the resting spore stage of $O$. weissflogii (Scott and Marchant, 2005) but no complete description of this stage is available. We also observed a larger rounder stage with even shorter apical horns, and therefore hypothesize that the rectangular form may be a resting cell or transition stage towards the actual resting spore, which would be the round form (suppl. Fig. S3). Both forms were absent at station M4 and M3, while the resting stage was most abundant at M2 and M1 in the upper Bottle net casts. The round spore stage was on average 10 times less abundant than the rectangular stage and was found at the same sites.

The small Proboscia inermis winter stages and abnormal forms $(10-25 \mu \mathrm{m})$ of this stage (suppl. Fig. 2 in Lafond et al., 2020), were the next contributors to winter/resting 
505

stage but were much less abundant, even though present at all sites, with a dominance at M4.

Several forms of Rhizosolenia with heavily silicified otaria- and clasper-lacking forms, such as Rhizosolenia polydactyla $f$. squamosa are thought to be resting spore/stage employed for overwintering but there is still a debate whether these morphotypes are winter resting stage or actual resting spore (Armand and Zielinski, 2001 and refs therein). This stage was present but as a very minor contributor in Phytonets and in one shallow Bottle net.

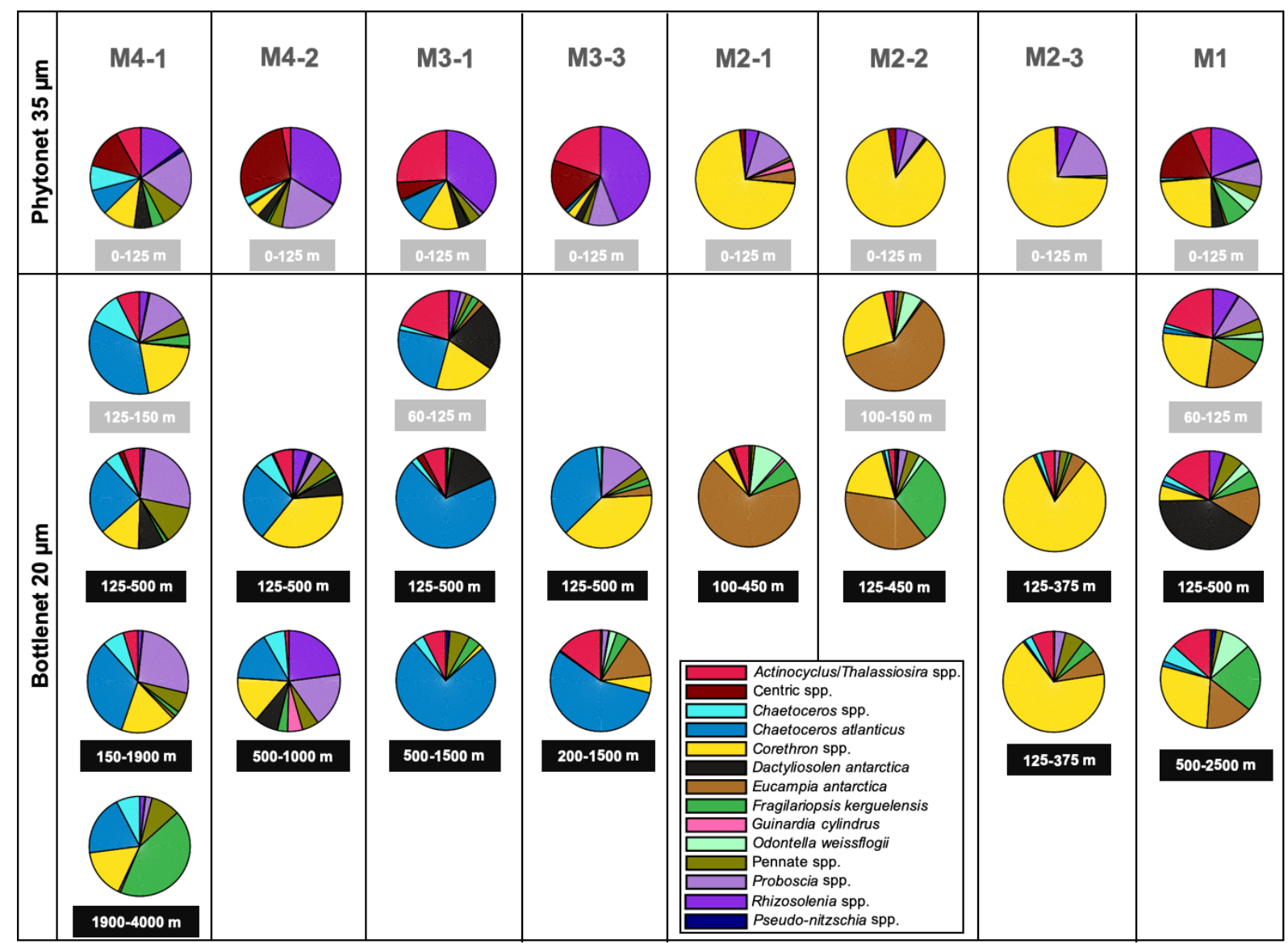

Figure 7: Relative contribution of diatom cells main taxa to $\mathrm{C}$ biomass (comprising intact cells only) in the Phytonet samples (upper pannel) and in the Bottle net samples (lower pannel) at each site and revisit. Collection depth is indicated below each pie chart.

\section{Relative carbon biomass}

Taxon-specific contribution to carbon biomass of intact cells only is presented in Fig. 7. Above the Kerguelen Plateau at M2, carbon biomass follows the same trend as abundances, with $C$. inerme $(77 \pm 8 \%)$ and Proboscia spp. (12 $\pm 6 \%)$ being the main contributors within the upper $125 \mathrm{~m}$ layer. Below $125 \mathrm{~m}$, Eucampia antarctica contributed to $69 \%$ of $C$ biomass at the first visit, before its biomass decreased significantly at the third visit, when it was replaced by C. inerme (67-83\%). Odontella weissflogii as resting cells and/or spores contributed to $10 \%$ at the first visit, and decreased with time, while F. kerguelensis contributed to $29 \%$ at the second visit. 
At the eastern station M1, Corethron spp. (24 \%) was also an important contributor in the upper $125 \mathrm{~m}$ layers, but other taxa also drove the C biomass: Rhizosolenia spp. (19\%, e.g. R. simplex, R. curvata), and other centrics (18\%, e.g. Asteromphalus hookeri, Actinocyclus octonarius, Azpeitia tabularis, Coscinodiscus spp., unidentified centrics etc.). Below the surface layer, key species contributing to $C$ biomass were similar to M2 (i.e. C. inerme, E. antarctica, F. kerguelensis), although species belonging to Actinocyclus/Thalassiosira complex became important (17 $\pm 3 \%$ within the three sampled layers) and the species Dactyliosolen antarctica dominated C biomass in the intermediate $125-500 \mathrm{~m}$ layer (41\%).

At the western stations M3/M4, the biomass of large centric species became dominant although they were numerically few. Indeed, within the upper 125 m layer, Proboscia spp. (mainly P. alata), Rhizosolenia spp. (e.g. R. curvata, R. polydactyla f. polydactyla), Actinocyclus/Thalassiosira spp. (e.g. A. curvatulus, A. octonarius, $T$. lentiginosa, $T$. tumida), and other centrics (e.g. Asteromphalus hookeri, and unidentified centrics) contributed together to $78 \pm 8 \%$ of $C$ biomass. In the intermediate layer, Chaetoceros atlanticus ( $39 \pm 21 \%$ ) was the main contributor to $C$ biomass, followed by the large centrics Corethron spp. (22 $\pm 19 \%$, mainly C. pennatum), Proboscia spp. (11 $\pm 12 \%$, mainly $P$. alata), and Dactyliosolen antarctica $(8 \pm 6 \%)$. A similar pattern extended to the deep layers with Chaetoceros atlanticus still driving $C$ biomass, except within the deepest layer sampled during the cruise (M4-1, 1900-4000 m) where Fragilariopsis kerguelensis contributed up to $43 \%$ of the $C$ biomass.

\subsection{Si and C concentrations and integrated stocks in the intermediate and deep layers}

\section{$B S i$ and diatom $C$ in Bottle nets}

Average and integrated biogenic silica and diatom carbon concentrations over the Bottle net sampling layers are presented in Table 4. Average concentrations of diatom C measured from intact cell counts were expectedly highest in all subsurface casts, with the highest value of $556 \mu \mathrm{g} \mathrm{C} \mathrm{m}^{-3}$ over $100-150 \mathrm{~m}$ at M2-2 (main contributor $E$. antarctica), followed by M4-1 over $125-150 \mathrm{~m}$ with $389 \mu \mathrm{g} \mathrm{C} \mathrm{m}^{-3}$ (main contributor $C$. atlanticus). M1 and M3 subsurface casts over $60-125 \mathrm{~m}$ contained much less intact diatoms, with 128 and $74 \mu \mathrm{g} \mathrm{C} \mathrm{m}{ }^{-3}$ respectively. Diatom $\mathrm{C}$ content then decreased at all sites with depth and reached the lowest values $\left(1-6 \mu \mathrm{g} \mathrm{m}^{-3}\right)$ in all casts extending to over $1000 \mathrm{~m}$ depth. The highest concentrations for the intermediate layer (between 125 and $500 \mathrm{~m}$ ) were found at M2-1 and M4-1, but decreased upon revisits to the same stations. Integrated diatom $C$ values ranged between 1 and $40 \mathrm{mg} \mathrm{C} \mathrm{m}^{-2}$ over the considered sampling layer, the highest diatom $C$ content was measured at M2-1 (40 $\mathrm{mg} \mathrm{C} \mathrm{m}^{-2}$ ) over $100-450 \mathrm{~m}$ followed by M4-1 (33 $\mathrm{mg} \mathrm{C} \mathrm{m}^{-2}$ ) over $125-500 \mathrm{~m}$. The lowest value for the intermediate layer was measured at M1 (2 mg C m${ }^{-2}$ over $\left.125-500 \mathrm{~m}\right)$.

Outside the plateau, BSi concentrations in the intermediate layer were highest at M4 (46 $\left.\mathrm{mg} \mathrm{Si} \mathrm{m}^{-3}\right)$, followed by M3 (18-12 $\mathrm{mg} \mathrm{Si} \mathrm{m}^{-3}$ ) and M1 (15 $\left.\mathrm{mg} \mathrm{Si} \mathrm{m}^{-3}\right)$. At M2, it reached $49 \mathrm{mg} \mathrm{Si} \mathrm{m}^{-3}$ at the third visit within the $125-375 \mathrm{~m}$ layer. Integrated concentrations were highest at M4-1 in the intermediate $\left(17,272 \mathrm{mg} \mathrm{Si} \mathrm{m}^{-2}\right)$ meso$\left(42,277 \mathrm{mg} \mathrm{Si} \mathrm{m}^{-2}\right)$ and bathypelagic $\left(28,374 \mathrm{mg} \mathrm{Si} \mathrm{m}^{-2}\right)$ suggesting an efficient export of $\mathrm{Si}$ in HNLC waters. At M2, integrated concentrations increased steadily between the 

was lower, meaning the Si stock increased significantly at depth.

Table 4: Amounts of intact diatom $C$ (from microscopical counts) and total biogenic silica (from chemical measurements) in Bottle net samples (>20 $\mu \mathrm{m}$ ) calculated as an average concentration (per $\mathrm{m}^{-3}$ ) in the considered layer, and as integrated values over the sampling depth (per $\mathrm{m}^{-2}$ ). For comparison, integrated $\mathrm{Si}$ and $\mathrm{C}$ stocks measured from discrete Niskin samples $(>0.4-0.7 \mu \mathrm{m})$ in the surface layer and over comparable depths are indicated in grey.

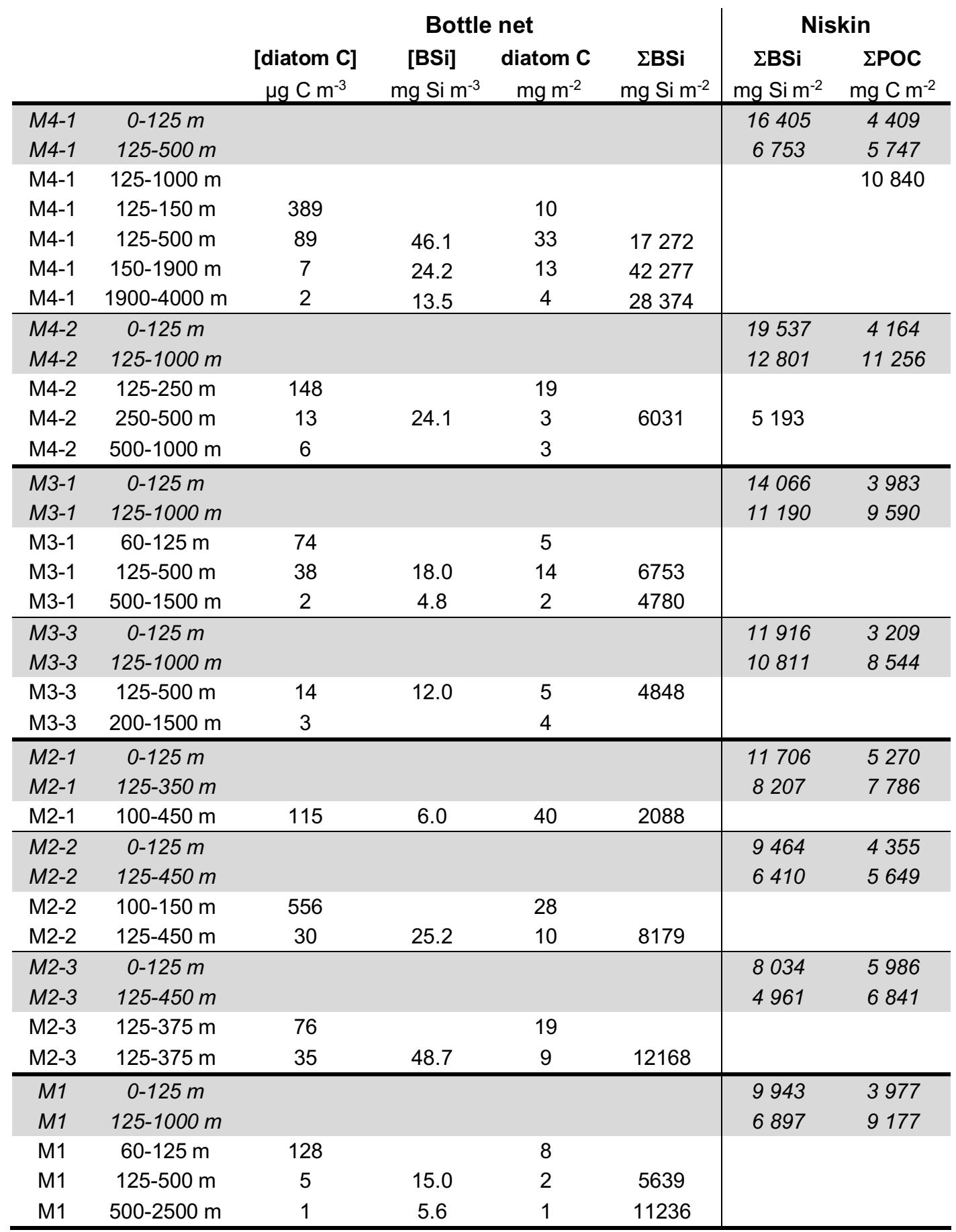


573 Biogenic silica and particulate organic carbon were measured chemically from discrete Niskin samples and integrated over depth layers identical to the Bottle net whenever possible for comparison. For BSi, this direct comparison over the exact same sampling layer was only possible on two CTD casts at M4-1 (125-500 m) and M2-2 (125-450 m). Results presented in Table 4 show that $\Sigma B S i$ in the Bottle net samples ( $\left.\Sigma B \mathrm{Bi}_{\mathrm{BN}}\right)$ were higher (2.5 and 1.3 times) than $\Sigma \mathrm{BSi}$ in Niskin bottles ( $\left.\Sigma B \mathrm{Bi}_{\text {Niskin }}\right)$ which was unexpected, considering that the Bottle net mesh size was $20 \mu \mathrm{m}$, while Niskin samples were filtered onto $0.4 \mu \mathrm{m}$. The Niskin and Bottle net mouth openings are very close $(\sim 7 \mathrm{~cm})$, and should not lead to different collection efficiencies. In this study, we can not conclude on whether the Bottle net collection efficiency is comparable to that of Niskin samples or if differences were only an effect of filtration size (both filter pore size and small vs large filtered volume effect). In future deployments, BSi and POC from Niskin bottles should be filtered onto $20 \mu \mathrm{m}$ in parallel for a direct comparison with the Bottle net samples.

Last, a comparison between diatom $C$ estimated from microscopical counts of Bottle net samples and $\Sigma P O C_{\text {Niskin }}$ over the same depth range was possible for 6 casts (except at M1) and showed that diatom $\mathrm{C}$ in Bottle net samples represented only 0.1 to $0.6 \%$ of $\Sigma P O C_{\text {Niskin }}$ over the $125-500$ or $125-1000$ m layer.

592

593

594

595

596

597

598

599

600

601

\subsection{Diatom lipid content}

The proportion of each diatom species containing lipid droplets (as stained with Nile Red) is presented in Fig. 8. Fragilariopsis kerguelensis appears to be the taxon that is most likely to sink out of the surface layer with lipids, and its contribution to total stained cell was major (70-80\%) at M4-1 and M1. Chaetoceros atlanticus, mostly in the form of single cells undergoing a sigmoidal stage or as spores (C. atlanticus bulbosum) was the next major taxon containing lipids, particularly at M3. At M2, Eucampia antarctica as well as Corethron inerme were also often showing lipid droplets, their relative contribution being similar to the evolution of total frustule abundance over the three visits. Finally, Odontella weissflogii resting stages/spores were also important lipid contributors during the first two visits at M2. 
$\%$ contribution to lipid content

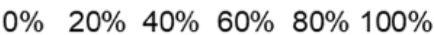

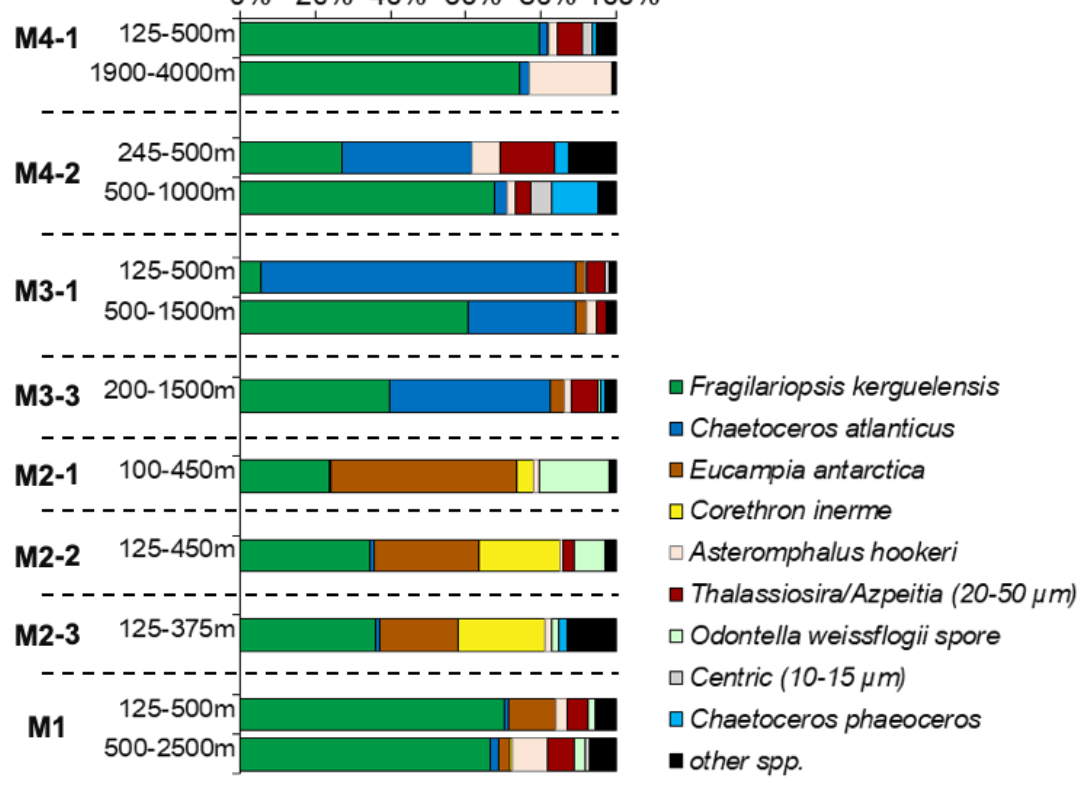

Figure 8: Relative contribution of main diatom taxa to lipid content, based on enumeration of cells positively labelled with Nile Red. Taxa contributing to less than $3 \%$ of lipid containing cells were pooled together in the category "other spp."

\subsection{Spore germination and induction experiments at M2}

Spore germination. At M2-2, 2 X 15 resting cells were collected from a subsurface Bottle net opened between 100 and $150 \mathrm{~m}$. After 12 days incubation, the aliquot incubated with both light and nutrients $(+\mathrm{Si}+\mathrm{P})$ showed a successful germination of all resting stages, and cell count amounted to 6,072 of actively dividing vegetative Odontella weissflogii cells (Table 5). Cells looked healthy and no empty frustules were found. In the light only treatment, the 15 initial cells yielded 3 times less vegetative cells, with a total of 2,048 cells. Some resting cells remained in the sample (10), and could be either the ungerminated initially isolated resting cells or new resting cells formed over the course of the incubation. In addition, 758 larger rounder forms of Odontella resting cells, suggesting transition towards a resting spore stage, were counted in this treatment only, accounting for another 1/3 of cells. Several abnormal valves and half vegetative/half resting spore cells were also observed (see suppl. Fig. S5). Assuming that all resting cells germinated in the first treatment, the total amount of $>6,000$ cells in 12 days is achieved with a growth rate of $0.5 \mathrm{~d}^{-1}$. In the light only treatment, assuming that only 5 out of the 15 resting cells germinated (since 10 intact resting cells were still observed in the sample), the final amount of $>2,000$ cells is also achieved with a growth rate of $0.5 \mathrm{~d}^{-1}$.

Table 5: Results of the spore germination experiment at M2-2 after 12 days incubation of 2 replicate samples containing 15 resting cells/spores of Odontella weissflogii in a light $+\mathrm{Si}+\mathrm{P}$ and in a light only treatment.

\begin{tabular}{l|cc|cc}
\hline \multirow{2}{*}{ Spore germination experiment } & \multicolumn{2}{|c|}{ Light +Si +P } & \multicolumn{2}{c}{ Light only } \\
\cline { 2 - 5 } & Live & Empty & Live & Empty \\
\hline Odontella weissflogii vegetative & 6072 & 0 & 2048 & 78 \\
Odontella weissflogii resting cell & 0 & 2 & 10 & 6 \\
Odontella weissflogii round form & 0 & 0 & 758 & 0 \\
Total Odontella weissflogii cells & 6072 & 2 & 2816 & 84 \\
\hline
\end{tabular}


Spore induction. At M2-1, 6 X $500 \mu \mathrm{L}$ aliquots from the 100-450 m Bottle net were incubated in low nutrient water (LNW) + light or in low nutrient water and dark conditions for 20 days. Results are summarized in Table 6. In the LNW +dark treatment, about $30 \%$ more Odontella weissflogii resting cells and round forms were observed at the end of the incubation, showing a higher probability to form spores in both nutrient and light deprived environments. A similar trend was observed for Eucampia antarctica winter forms, which were 3 times more abundant in this treatment as well.

Table 6: Results of the spore induction experiment at M2-1 after 20 days of incubation of $2 X 3$ replicate samples collected from phytonets and incubated in low nutrient water (LNW) in surface light conditions and in the dark.

\begin{tabular}{l|cc|cc}
\hline \multirow{2}{*}{ Spore induction experiment } & \multicolumn{2}{c|}{$\begin{array}{c}\text { LNW + light } \\
\text { treatment }\end{array}$} & \multicolumn{2}{c}{$\begin{array}{c}\text { LNW + dark } \\
\text { treatment }\end{array}$} \\
\cline { 2 - 5 } & Live & Empty & Live & Empty \\
\hline Odontella weissflogii resting cells & 64 & 81 & 91 & 65 \\
Odontella weissflogii resting spores (round form) & 4 & 9 & 9 & 5 \\
Eucampia antarctica winter form & 99 & 305 & 297 & 500 \\
\hline
\end{tabular}

\section{Discussion}

\subsection{Nature of the deep particle stock}

The number of identifiable individual diatom frustules collected with the Bottle net in deep waters around Kerguelen islands by the end of summer was not negligible (107$10^{8}$ cells $\mathrm{m}^{-2}$ ) and the deep diatom stock (below $125 \mathrm{~m}$ ) was one order of magnitude higher than the stock present in the upper (0-125 m) layer (Lafond et al., 2020). It was also 3 orders of magnitude higher than the concentration of single phytoplankton cells measured on average by Agusti et al. (2015) in the 2,000-4,000 m layer in the subtropical Ocean. This is not surprising considering the large annual diatom bloom event occurring around Kerguelen Islands due to natural Fe-fertilization, which has been documented during previous cruises in the same area (Armand et al., 2008a; Lasbleiz et al., 2016) and the shallower sampling depths. The export of diatom cells at depth was also expected considering that the MOBYDICK cruise occurred at the end of summer during the demise of the bloom, as previously documented from sediment trap samples in the same region (Rembauville et al., 2015), from sediment trap material over the Crozet plateau region (Salter et al., 2012; Salter et al., 2007) or further into the Australian sector of the Antarctic Zone (Rigual-Hernández et al., 2016; RigualHernández et al., 2015). On the other hand, the dominance of single diatom cells (93\%) over any other type of particles such as fecal pellets, phytodetritus and aggregates was unexpected. We have no other elements of comparison regarding the contribution of aggregates and fecal pellets in the subtropical ocean, as these were not reported in Agusti's Bottle net study.

Given the size of the dominant taxa observed in our study $(20-50 \mu \mathrm{m})$, it is unlikely that single cells sank to depth without being integrated to larger aggregates. It is possible that the Bottle net sampling could have promoted the disaggregation of phytodetritus during the upcast and water flow through the $20 \mu \mathrm{m}$ net, potentially explaining the very low contribution of aggregates and fecal pellets. However, the state of cells observed in microscopy directly after sampling on board in each sample, the absence of large 
mucus/TEP aggregates and the morphological shape of diatoms and other cells (frustules and setae intact) suggest that these particles were likely not aggregated at the time of sampling. The similarity of the taxonomic diatom composition in the Bottle nets compared to the above surface layer phytonets (Fig. 6) furthermore suggests a rapid export mode of diatoms, which has already been hypothesized in the same region with observations of similar taxonomic composition between the surface layer and sediment taps moored at $300 \mathrm{~m}$ (Blain et al., 2020). We therefore hypothesize that these cells sank rapidly out of the surface layer, included in loose phytodetritus or aggregates which disaggregated in situ prior to collection, due to shear stress in the water column or to bacterial mineralization of TEP/colloids holding aggregates together.

Clearly, these cells were not exported as fecal pellets, given for instance the state of Chaetoceros atlanticus sigmoidal stages with unbroken setae, particularly in the deep cast (1900-4000 m) at M4-2. Microscopic examinations also allowed to observe loose aggregates still holding together as well as intact tightly packed fecal pellets (suppl. Fig. S4) which suggests that the Bottle net sampling was not disrupting particles or aggregates in a major way.

On one occasion, at one of the two 125-375 m casts performed at M2-3, numerous large aggregates were observed (14\% of total particles, but representing practically the entire inert particle fraction) together with cells covered with loose organic material. Unfortunately, it was complicated to estimate their $C$ biomass due to their heterogeneity (e.g. density, composition etc.), but their contribution to $C$ biomass was likely not negligible for this cast, since most of the other particles were empty diatom frustules. Interestingly, those large aggregates were not observed in the exact same layer 8 hours later (decrease in abundance by a factor X100), indicating a very brief export event at a high sinking rate. This station was sampled few days after a strong storm event which could have promoted both their physical aggregation through vertical mixing and their rapid export. Their disapperance 8 hours later further suggests an export event in the form of loose aggregates, that were not cohesive enough to stay aggregated below the surface layer. This observation could reconcile our data showing mostly single cells in the the intermediate layers, with the mecanism of rapid export proposed by Blain et al. (2020), which would lead to a rapid flushing of the surface layer of diatoms in the form of aggregates, once reached a critical cell concentration and stickiness threshold value. In another study carried out in the Antarctic Zone, sediment trap data results suggested a fast and undisturbed transport of particles between 2000 and 3700 , and sinking velocities of $210 \mathrm{~m}^{-2} \mathrm{~d}^{-1}$ of the major diatom taxa were estimated (Rigual-Hernández et al., 2015).

Phytodetrital aggregates were previously reported to contribute significantly to export fluxes in this region. During ANTARES I, a thick fluff layer containing high pigment levels (up to $13 \mu \mathrm{g} \mathrm{L}^{-1}$ ) was observed west of Kerguelen at more than 3,000 m depth (Riaux-Gobin et al., 1997), while during spring (KEOPS 2 cruise), phytodetrital aggregates were the most abundant type of particles collected by polyacrylamide gel sediment traps (Laurenceau-Cornec et al., 2015). A study of surface sediment samples in the same area during the spring bloom in 2005 (KEOPS cruise) also revealed a number of intact diatom frustule on the seafloor, suggesting an efficient transport mode 
of single cells at depth (Armand et al., 2008b), but which could also be the result of an aggregation/sinking/disaggregation sequence.

Finally, due to the very short period of particle collection (during a CTD upcast), we cannot exclude that we missed other important pulse export events such as the one observed at M2-3, especially at the end of the productive season which is often characterized by an intense and brief export event called the "fall dump" (Kemp et al., 2000; Quéguiner, 2013).

\subsection{Mortality modes}

\section{Parasitic infection}

During the cruise, the diatom contribution to $\mathrm{C}$ biomass was the highest above the plateau at M2 (Table 4). An important development of long filaments of Corethron inerme occurred in the course of three successive visits over nearly a month, and resulted in a doubling of diatom $\mathrm{C}$ biomass over the 0-100 m layer. This species was also mixed with a few $(<10 \%)$ other large-size tubular centrics such as Rhizosolenia spp. and Proboscia spp, which likely occcupied the same ecological niche. These species, with frustules relatively thinner than most other diatom taxa present at the other sites, grew at the station most depleted in silicic acid (1.2 to $2.6 \mu \mathrm{M})$, which could indicate their adaptation to low Si levels. During live observations on board, parasitic infection of many cells was clearly visible, with some cells filled with small black parasites $<1 \mu \mathrm{m}$ in size (suppl. Fig. S2). This was the only site (except a single occurrence at M4-2) where such parasitic infection was observed. Single cell sequencing of isolates picked on board and co-occurrence network analyses suggest that these parasites belong to the Syndiniales group, which was not previously known to infect diatoms (Sassenhagen et al., 2020). Interestingly, at M2-1, Corethron was only a minor contributor to the intermediate layer stocks, which was initially dominated by Eucampia. The relative contribution of Corethron at intermediate depth increased over time, probably reflecting the sinking of infected cells, as is visible on the third visit with $15 \%$ of infected Corethron cells observed in the $125-375$ m layer. The percentage of viable cells in the surface samples decreased from $47 \%$ on the first visit to $6 \%$ on the last (Table 2), reflecting massive cell mortality, which is the likely result of this parasitic infection. The apparition of infected cells below the euphotic layer at M2-3 could be the result of susbsequent sinking of cells loosing their membrane integrity and their buoyancy, but could also be linked to a strong storm event occurring between M2-2 and M2-3 that disrupted the surface layer and induced mixing with the intermediate layer. It is however not clear from our results if the parasitic infection led to preferential sinking of Corethron empty cells, or if this was just the result of the temporal increase of Corethron abundance over the three visits and mixed layer disruption following the storm. It would seem more likely that infected cells are rather lysed and remineralized in the surface layer through the viral shunt than massively exported at depth. However, a recent study conducted in the North Atlantic indicated that viral infection of a ballasted biomineral containing phytoplankton such as Emiliania huxleyi appeared to stimulate vertical export flux and rather enhanced the biological $\mathrm{C}$ pump (Laber et al., 2018). Other types of infections were observed during live observations of net material on board, such as small swimming nanoflagellates cells 
invading Rhizosolenia spp. cells, or parasites flowing out of a Ceratium lineatum cell, which suggests that parasitic infections were actively occurring over the plateau at the end of the productive season. Zoosporic and fungal parasitic infection, in addition to viral and bacterial infection, are still a large unknown in our comprehension of diatoms as well as other phytoplankton's bloom termination and are thought to be much more abundant than reported in the literature (Gutiérrez et al., 2016; Scholz et al., 2016). Si limitation has furthermore been shown to facilitate viral infection of diatoms in a highly productive coastal system (Kranzler et al., 2019). In our study, parasitic infection was also observed at the most $\mathrm{Si}$ limited station (Si:N ratios of $0.05-0.11$ ) and we hypothesize that the thinner frustule together with nutrient limitation could also facilitate the parasitic infection of large cylindric centrics such as Corethron, Rhizosolenia and Proboscia.

\section{Grazing processes by microzooplankton}

The high contribution of both dinoflagellates and tintinnids in the other microplankton compartment and the dominance of small-sized $(<100 \mu \mathrm{m})$ aggregates over fecal pellets in the Bottle net samples is also more consistent with the dominance of an active microbial food web reflecting the demise of the bloom rather than with a more developped mesozooplankton compartment and longer food chains. Interestingly, minipellets $(<30 \mu \mathrm{m})$ produced by Rhizaria were a major part of the detrital stock in all Bottle net samples. Their origin was confirmed by direct observations on board (suppl. Fig. S4) of active grazing on diatoms by the phaeodarian group Protocystis spp. (mostly $P$. swirei and P. tridens). This group of phaeodarians is known to feed on bacteria, algae and also fecal pellets or organic matter aggregates. Numerous smallsized $(80-160 \mu \mathrm{m})$ Protocystis were observed ingesting whole cells of Fragilariopsis kerguelensis and excreting minipellets comprised between 10-30 $\mu \mathrm{m}$, filled with $F$. kerguelensis debris as well as with other undetermined cells. Such an active grazing by phaeodarians on diatoms associated to the production of minipellets has seldom been reported except in older studies in the Pacific Ocean (Gowing and Silver, 1985), and in the Southern Ocean in the Antarctic peninsula (Gonzalez, 1992) and in the Weddell Sea (Gowing, 1989). Despite their small numerical abundance, this group, together with other siliceous Rhizaria, could have an important contribution to the $\mathrm{Si}$ stocks measured in the Bottle net, given their elevated skeleton Si content (in our study $\left.2 \mathrm{nmol} \mathrm{Si} \mathrm{cell}{ }^{-1}\right)$ compared to diatoms, and their ability to concentrate Si debris in minipellets (Nakamura and Suzuki, 2015 and references therein; Leblanc et al., in prep.). The ecological role of these phaeodarians is likely to be significant as evidenced by previous studies around the Antarctic peninsula (Gonzalez, 1992), but it has received little attention until very recently, when new studies based on DNA metabarcoding have revealed the global importance of Rhizaria (Stukel et al., 2018) and phaeodarians in the particle vertical export (Gutierrez-Rodriguez et al., 2019). In a survey from 1988 in the Scotia Sea and the Weddell-Scotia confluence, integrated minipellets reached $10^{6} \mathrm{~m}^{-2}$ values and were 5 orders of magnitude more abundant than krill feces (Gonzalez, 1992). In the Weddell Sea, phaeodarians were in turn actively grazed by salps such as Salpa thompsoni (Gowing, 1989), thereby linking the microbial food web to higher trophic levels. Other phaeodarians such as Phaeodina 
antarctica were also observed in our study and agglutinated both whole diatom valves and silicoflagellates skeletons, resulting in elevated particulate $\mathrm{Si}$ cell- $^{-1}$. Hence Rhizaria, through their siliceous skeletons and fecal pellets, and specifically minipellets, appear as active contributors to the downward Si flux at the end of the productive season.

\section{Grazing processes by mesozooplankton}

Mesozooplankton abundance was on average lower during the spring cruise (58 to $1,249 \times 10^{3}$ ind. $\mathrm{m}^{-2}$ ) that took place in 2010 in the same area (KEOPSII), compared to this study (64 to $860 \times 10^{3}$ ind. $\mathrm{m}^{-2}$, A. Delegrange pers. comm.) reflecting the lower food availability in the surface layer at the end of summer. Despite the relative small contribution of fecal pellets to the detrital deep stocks in the Bottle net samples, signs of active mesozooplankton grazing (probably by copepods which was the dominant zooplankton group or amphipods like Themisto gaudichaudii frequently observed from micronekton sampling) were clearly indicated by the presence of crunched frustules debris outside as well as inside fecal pellets. Potential prey selection was observed, as crunched frustules were only observed for Fragilariopsis kerguelensis and several centric diatoms such as Thalassiosira lentiginosa, Azpeitia tabularis and Asteromphalus hookeri (suppl. Fig. S1). Other dominant diatoms such as Eucampia antarctica, Corethron inerme or Chaeroceros atlanticus were never observed with crunch marks, even though they were observed in SEM in fecal pellets, suggesting different types of grazers or feeding behaviors. During the EIFEX Fe-fertilization experiment, Assmy et al. (2013) reported that the thick Si frustule of $F$. kerguelensis made it less palatable for mesozooplankton and crunched end cells were interpreted as a result of copepods being deterred by the high energy expenditure needed to crush these preys (Hamm et al., 2003). Yet, in our study, fecal pellets observed in SEM also contained a number of crushed (and sometimes whole) F. kerguelensis valves together with other similarly heavily silicified diatoms such as Eucampia antarctica, Chaetoceros atlanticus, Corethron criophilum as well as many small intact Chaetoceros resting spores indicating active grazing and ingestion (Fig. 4). It is possible that the high lipid content of these species (Fig. 8) made them more palatable for zooplankton upon entering the winter diapause period. The SEM observations of fecal pellets $<100 \mu \mathrm{m}$ and the diversity that is observed thanks to many identifiable frustules (Fig. 4) suggest that even diatoms with thick frustules are actively grazed by copepods and other mesozooplankton species. However, we were not able to identify whether the preferential downward pathway for $F$. kerguelensis was sinking as single cells or included in fecal pellets. Furthermore, pulverized frustule debris were commonly observed during on board examinations but could not be quantified. Improved techniques would be needed to isolate fecal pellets, quantify their relative $\mathrm{Si}$ vs. C contents together with a precise taxonomic identification of frustule remains. Clearly, the $\mathrm{Si} / \mathrm{C}$ ratio of these fecal pellets should be disproportionnally high compared to the single cell flux, even if it was dominated by empty frustules, if one considers the hundreds of siliceous frustules tightly packed into each fecal pellet. 
Diatom resting stages were more frequently observed in the HNLC waters west of Kerguelen and over the plateau than at station M1, and were only observed in centric species. The winter stage/resting spore formation is usually preferentially observed in centric diatoms and in the coastal environments, possibly allowing cells that have sunk to the sediments to resurface upon the next mixing event (McQuoid and Hobson, 1996). At M4 and M3 a particular solitary stage of Chaetoceros atlanticus, with sigmoidal setae (which we hypothesize is a resting cell form) and in lesser abundance, the spore form (C. atlanticus $f$. bulbosum) were dominant. On the plateau area, the abundance of the $C$. atlanticus complex was minor and may have resulted from some eastward advection, mixing some of these cells with the local community.

The plateau, which was the most Si-limited region at the end of summer (1.2 to $2.6 \mu \mathrm{M}$ $\mathrm{H}_{4} \mathrm{SiO}_{4}$ and $\mathrm{H}_{4} \mathrm{SiO}_{4}$ :total $\mathrm{N}_{\text {mineral }}$ ratios as low as $0.05-0.11$ ), was dominated by the winter stage of Eucampia antarctica in the process of sinking out of the surface layer following a previous bloom, as they were more abundant in intermediate layer Bottle nets than in the surface Phytonets. Our results are consistent with observations reported for the Crozet Islands diatom export study in a similar comparison of an Fefertilized plateau vs. an Fe-limited station further off in the open ocean (Salter et al., 2012). In this study, the contribution of Eucampia antarctica viable heavily silicified and well preserved winter stages to diatom export flux at depth on the plateau was dominant (up to $71 \%$ contribution), while the vegetative stage was almost entirely absent. As nitrate was non-limiting, the authors suggested that low dissolved Fe and silicic acid concentrations at the end of the growth season were plausible triggers for the development of the winter stage and its subsequent sinking, which was tightly correlated to the enhanced C flux measured on the plateau (Salter et al., 2012). Winter forms of Eucampia antarctica were also abundant on the sediment floor of the Kerguelen Plateau (Armand et al., 2008b), confirming the important role of this emblematic species to the $\mathrm{C}$ pump in Fe-fertilized Southern Ocean island areas.

This species also co-occurred with Odontella weissflogii, which were likely sporulating, as resting cells and spores were present in the shallow Bottle net samples and much less abundant at depth than E. antarctica. Microscopic observations on board revealed healthy looking spores (packed with lipids), which further confirms the recent sporulation and on-going sedimentation event.

The exploratory sporulation/germination experiments conducted at M2 strongly suggest that Si availability was the key trigger for spore formation, since the light treatment yielded 3 times less vegetative cells of $\mathrm{O}$. weissflogii than the Si+light treatment (Table 5). Furthermore the number of abnormal valves and general state of germinated cells were a clear indication of Si limitation, while nitrate was still sufficient $(>21 \mu \mathrm{M})$. In the sporulation experiment the light deprivation in low nutrient waters stimulated a $30 \%$ increase in $O$. weissflogii resting stages, while $E$. antarctica winter stages increased by a factor of 3 (Table 6), which could reflect different speciesspecific responses to environmental triggers. samples below the mixed layer at M2 and M1 (Lafond et al., 2020) but were neither 
observed in Phytonets nor Bottle nets because of too large mesh sizes (35 and 20 $\mu \mathrm{m})$. Even though in small abundances, they however could contribute up to $40 \%$ of diatom $\mathrm{C}$ biomass at these sites below the mixed layer, and are therefore potentially largely underestimated in the deep Bottle net casts, which do not allow sampling such small sized cells. These observations are congruent with previous reports of increased dominance of Chaetoceros Hylaochaete resting spores (CRS) in trap samples (Rembauville et al., 2016) and of dominance of CRS together with E. antarctica in sediments over the Kerguelen plateau (Armand et al., 2008b). New findings also show that viral infection of the bloom-forming genus Chaetoceros could induce mass formation of resting spores as a defense strategy (Pelusi et al., 2020), which is yet another mecanism that could lead to mass carbon export events by diatom spores.

\subsection{Silicification degree and role in export}

A schematic graph of diatom communities, Si:C stoichiometry and key processes both on and off-plateau is presented in Fig. 9. Clear differences over and outside the plateau for $\mathrm{Si} / \mathrm{C}$ stoichiometrical ratios in particulate matter based on diatom carbon biomass were observed with the highest average $\mathrm{Si}: \mathrm{C}_{\text {diatoms }}$ ratios from Niskin bottle at offplateau stations $(2.7 \pm 0.7)$ and lowest on the plateau $(0.6 \pm 0.2)$ (Lafond et al., 2020).

Unfortunately we cannot produce a direct comparison from the Bottle net samples due to lacking POC data, but floristic fauna as well as microscopic observations confirmed the dominance of more heavily silicified species outside the Fe-fertilized plateau with a large dominance of the Chaetoceros atlanticus 'bulbosum' complex and $F$. kerguelensis at M4/M3 (Fig. 6). Frustule abundance was dominated by these two taxa, evidencing their elevated contribution to the downward Si flux. F. Kerguelensis is known to be the dominant species in sediment and main opal contributor of the summer POOZ (Permanently Open Ocean Zone), where it accounts for $\sim 80 \%$ of the total diatom assemblage (Crosta et al., 2005) and its maximum occurrence is reported in waters $1-7^{\circ} \mathrm{C}$ (Jacques, 1983) which covers the temperature range measured during MOBYDICK $\left(2-5^{\circ} \mathrm{C}\right)$. In our study region, the contribution of $F$. kerguelensis in the sediment varies between 30 and $75 \%$, while $T$. lentiginosa, which was also abundant here, is the second most abundant taxon in Southern Ocean sediments with a reported range from $5-30 \%$ and has the same pattern of distribution in the sediments than $F$. kerguelensis (Crosta et al., 2005; Shukla et al., 2016). This is consistent with our findings showing that $F$. Kerguelensis is the dominant contributor to biomass in the deepest sample at M4 (Fig. 7), suggesting that it is the most efficient species at injecting $\mathrm{C}$ below the $2000 \mathrm{~m}$ horizon. On the plateau (M2), the more weakly silicified Corethron inerme was dominant in the surface layer, but the deep particle stock was also enriched with more heavily silicified species such as $E$. antarctica and $F$. kerguelensis even though in lesser numbers than west of Kerguelen.

It is notable that $F$. kerguelensis silicification degree, quantified with a silicification fluorescent probe (Lafond et al., 2020), was higher at M4/M3/M1 than at M2, reflecting the different ecological situations regarding Fe limitation. Hence, both taxonomic differences (mix of Corethron with Eucampia and Fragilariopsis) and lesser silicification degree of the dominant species can explain the lower $\mathrm{Si} / \mathrm{C}_{\text {diatom }}$ ratios on the plateau. 
Finally, Eucampia and Fragilariopsis were the dominant contributors to the Si flux while 934 Corethron inerme was the main contributing species to $\mathrm{C}$ export, in particular upon the 935 last visit at M2 (Fig. 7), again showing differences in the relative contribution of diatom 936 species to $\mathrm{Si}$ and $\mathrm{C}$ export.

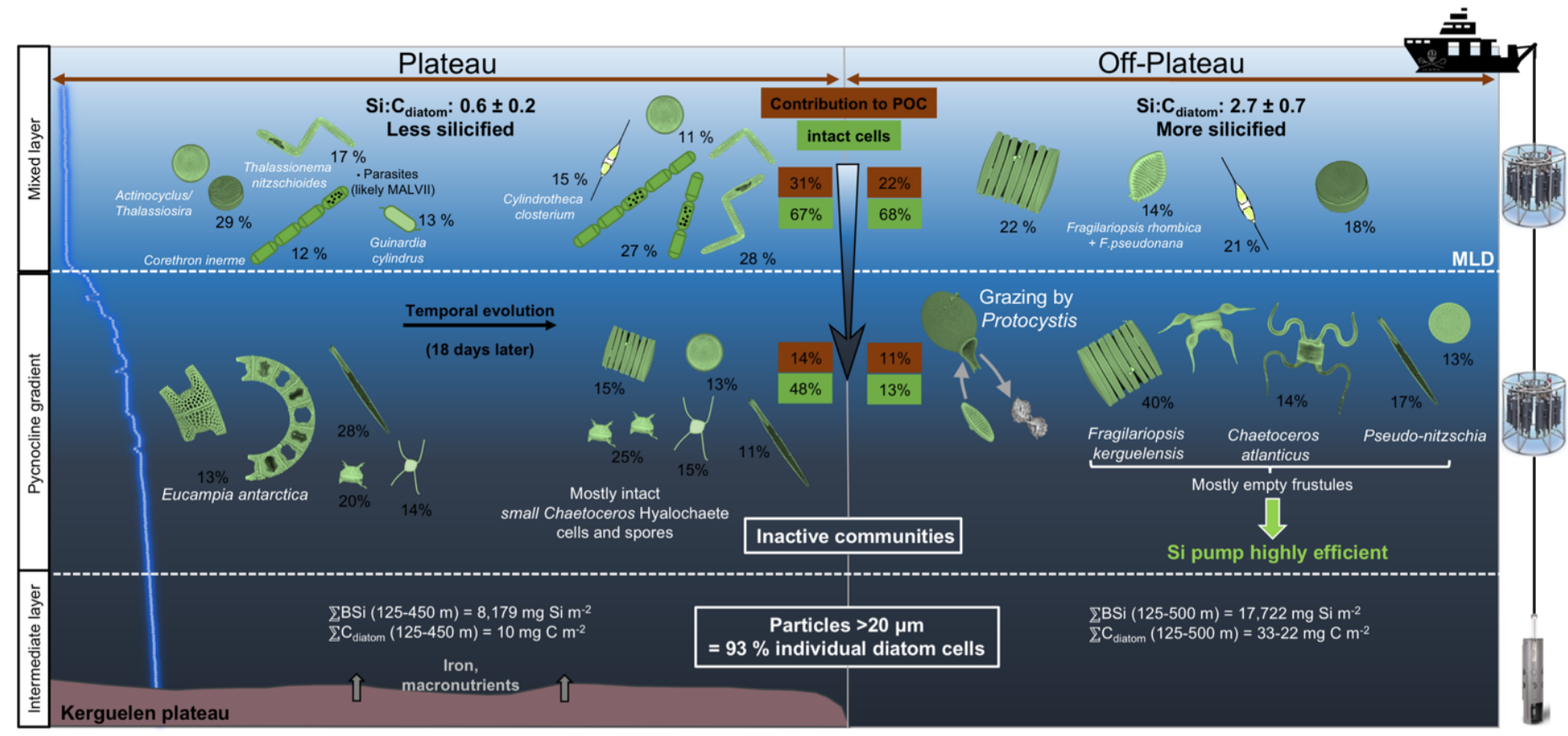

938

939

940

941

942

943

944

945

946

947

948

949

950

951

952

953

954

955

956

957

958

959

Figure 9: Conceptual schematic of the main results obtained above the Kerguelen Plateau at the naturally Fe-fertilized station (M2) and off-plateau in the HNLC station (M4). The blue curve on the left illustrates the vertical evolution of density with depth at station M2. Instruments used to sample the different water layers are displayed on the right handside. Only major taxa ( $>10 \%$ of total abundance) are represented here for clarity, and their relative contribution to abundance is indicated in black numbers.

\section{Conclusions}

The similarity of deep Bottle net samples with the overlying layer is not compatible with very slow sinking particles or suspended cells with no flux, and indicates rather fast export mechanisms to depth or intense mixing. The Bottle net does not allow to determine whether the collected material was part of the slow/fast sinking flux or a fraction of suspended particles, as can be done with a marine snow catcher for instance (Riley et al., 2012). A combination of such tools, together with gel traps (Lundsgaard, 1994) would allow to make progress on the characterization of the C attenuation curve in the meso- to bathypelagic ocean. In situ sinking velocities of aggregates and fecal pellets are still difficult to estimate due to the lack of data especially on their porosity and density, while size may not be the best predictor for this process (Iversen and Lampitt, 2020; Smith, 2014). Our results suggest a rapid export of diatom cells in the form of loose aggregates/phytodetritus, that reached intermediate and deep layers, but which were disaggregated prior to sampling, explaining the dominance of single cells in bottle net. 
Our study shows that the concept of the Bottle net offers new investigative capabilities to the existing toolbox of instruments (McDonnell et al., 2015). The tools to be developped in this direction should prove a very useful complement to collect suspended and sinking particles in the ocean's interior. The Bottle net allowed to carry out a detailed study of diatom taxonomy, $\mathrm{C}$ biomass, physiological state of cells, trophic behaviour and life cycles on depth-integrated concentrated material which could not have been obtained from discrete deep Niskin samples, in which particle concentration is much too low for such analysis. In particular, it allowed to identify various mortality modes at the end of the final summer bloom. Fragilariopsis kerguelensis, which was previously considered as a very resistant species against grazers (Hamm et al., 2003; Assmy et al., 2013; Quéguiner, 2013), has been shown here to be actively grazed by mesozooplankton with a lot of crunched frustules, but also ingested by phaeodarian barely larger than the diatom cell length. High contents of crushed frustules debris observed in fecal pellets and minipellets also showed that this species is indeed palatable for various grazers. The Bottle net also allowed us to collect small-sized particles and to evidence that minipellets were the dominant fecal material in the water column at this stage of the season. Unfortunately, we could not estimate their contribution to the deep $\mathrm{C}$ stocks, even though previous studies have evidenced that it could be important.

Finally, the Bottle net could also help identify sporulation events linked to surface Silimitation over the plateau and evidence that parasitic infection of diatoms could help inject both $\mathrm{C}$ and $\mathrm{Si}$ in the form of whole intact cells below the mixed layer, rather than be remineralized entirely in the surface layer. Much more emphasis needs to be placed on the end of bloom periods during field work, in order to be able to progress on identifying processes leading to the demise of the blooms and to understand how parasites and viruses may alter species succession and the fate of primary produced C. We also stress that live observations on board are absolutely necessary in identifying different trophic behaviours, such as infection by parasites that can be easily overlooked when examining fixed samples back at the ground-based laboratory.

Future sampling strategies in this region (and presumably on a global scale) will need to incorporate the biogeochemical and taxonomic characteristics of all components of vertical particle flux in a more integrated manner, allowing the intensity of the biological carbon pump to be more precisely related to environmental conditions. This strategic development proves to be crucial to provide elements for predicting the evolution of the biological carbon pump in these times of rapid climate change.

\section{Acknowledgments}

We thank B. Quéguiner, the PI of the MOBYDICK project, for providing us the opportunity to participate to this cruise, the chief scientist I. Obernosterer and the captain and crew of the R/V Marion Dufresne for their enthusiasm and support aboard during the MOBYDICK-THEMISTO cruise (doi:10.1BE00/1F00040G). This work was supported by the French oceanographic fleet ("Flotte océanographique française"), the French ANR ("Agence Nationale de la Recherche", AAPC 201B program, MOBYDICK Project number: ANR-1B-CE01-001G), and the French Research program of INSH- 
CNRS LEFE/CYBER ("Les enveloppes fuides et l'environnement" - "Cycles biogéochimiques, environnement et ressources"). We also thank Dr. D. Vaulot and I. Probert who gave us access to the Phenom-Pro at the Roscoff Biological Station. The authors wish to thank Frédéric Le Moigne for constructive disscussions on this paper.

The authors declare that they have no known competing financial interests or personal 
An overview of the diversity of all taxonomic groups found in Niskins, phytonet and Bottle nets can be found here https://plankton.mio.osupytheas.fr/mobydick-2018/. An overview of the composition of fecal pellets and aggregates in both light microscopy and SEM is available here https://plankton.mio.osupytheas.fr/mobydick-fecal-pellets/
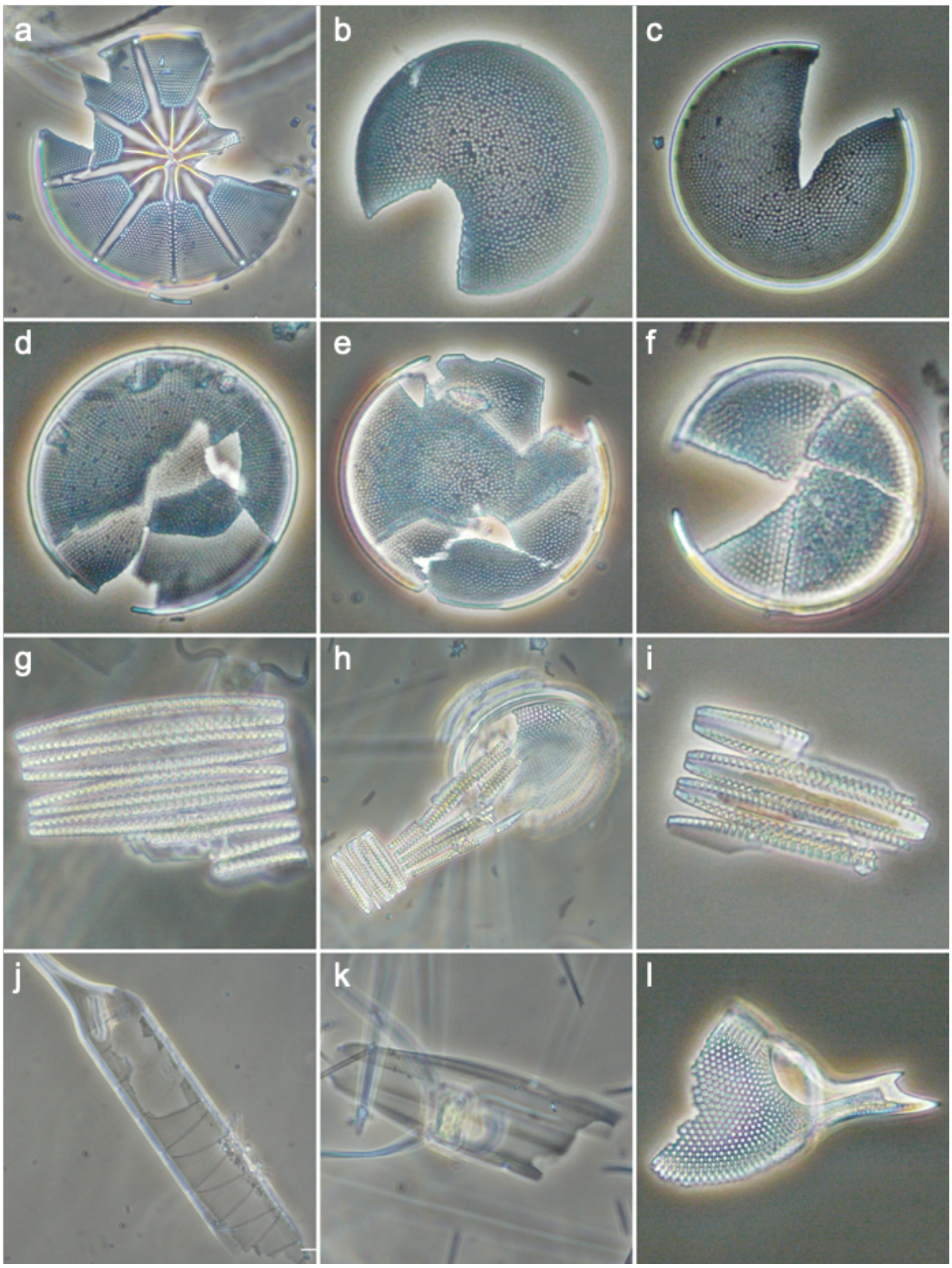

Suppl. Figure S1. Selection ofimages showing crunched siliceous diatom frustules (a to $\mathbf{k}$ ) and Phaeodarian skeleton (I), indicating active mesozooplankton grazing. a. Asteromphalus hookeri, b-f. Thalassiosira lentiginosa, g-h. Fragilariopsis kerguelensis, j. Proboscia sp., k. Membraneis sp. I. skeleton of Protocystis sp. (Phaeodaria). 


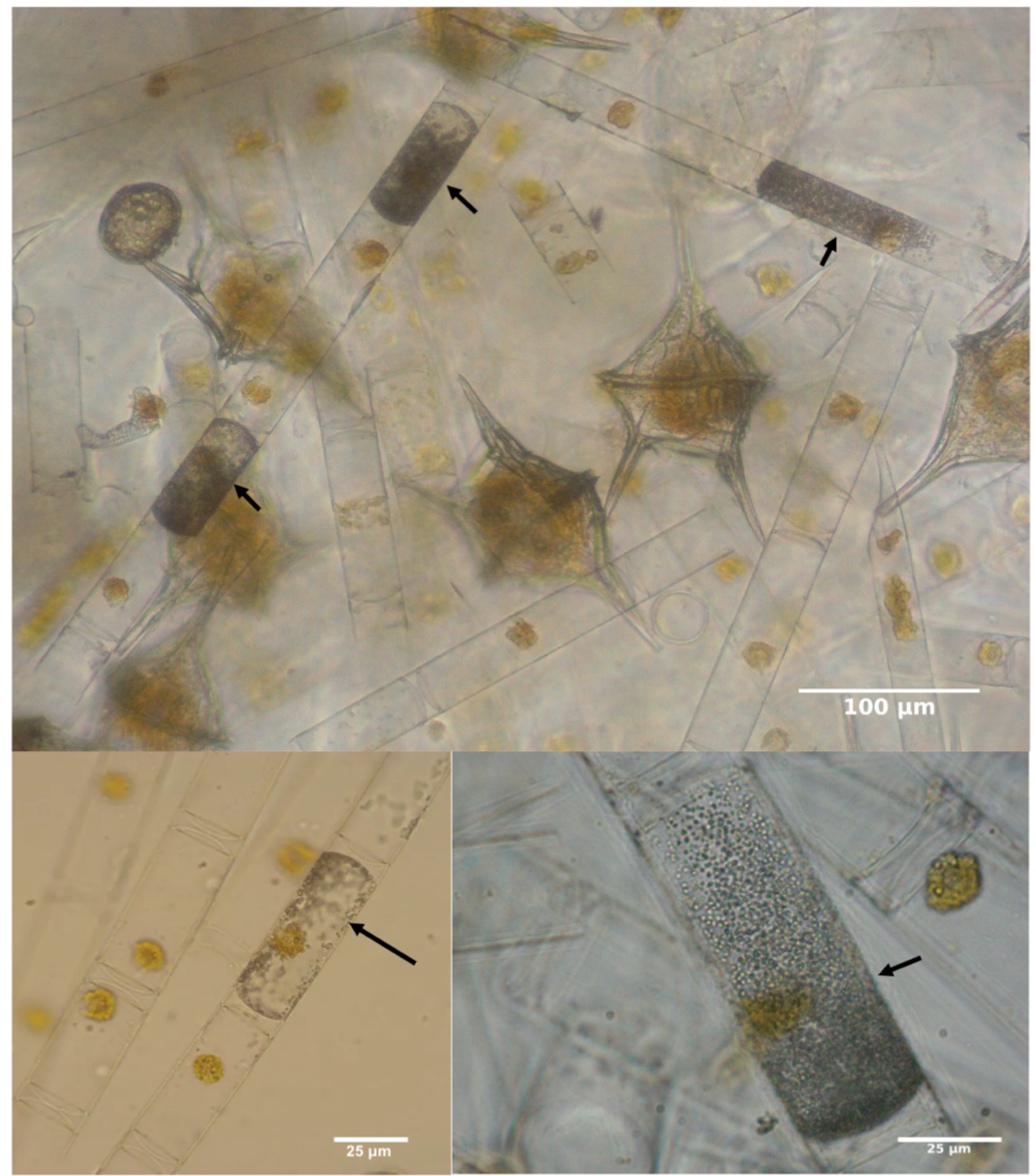

1027 Suppl. Figure S2: Images showing a parasitic infection of Corethron inerme colonies at station M2. 1028 Black arrows indicate infected cells. 

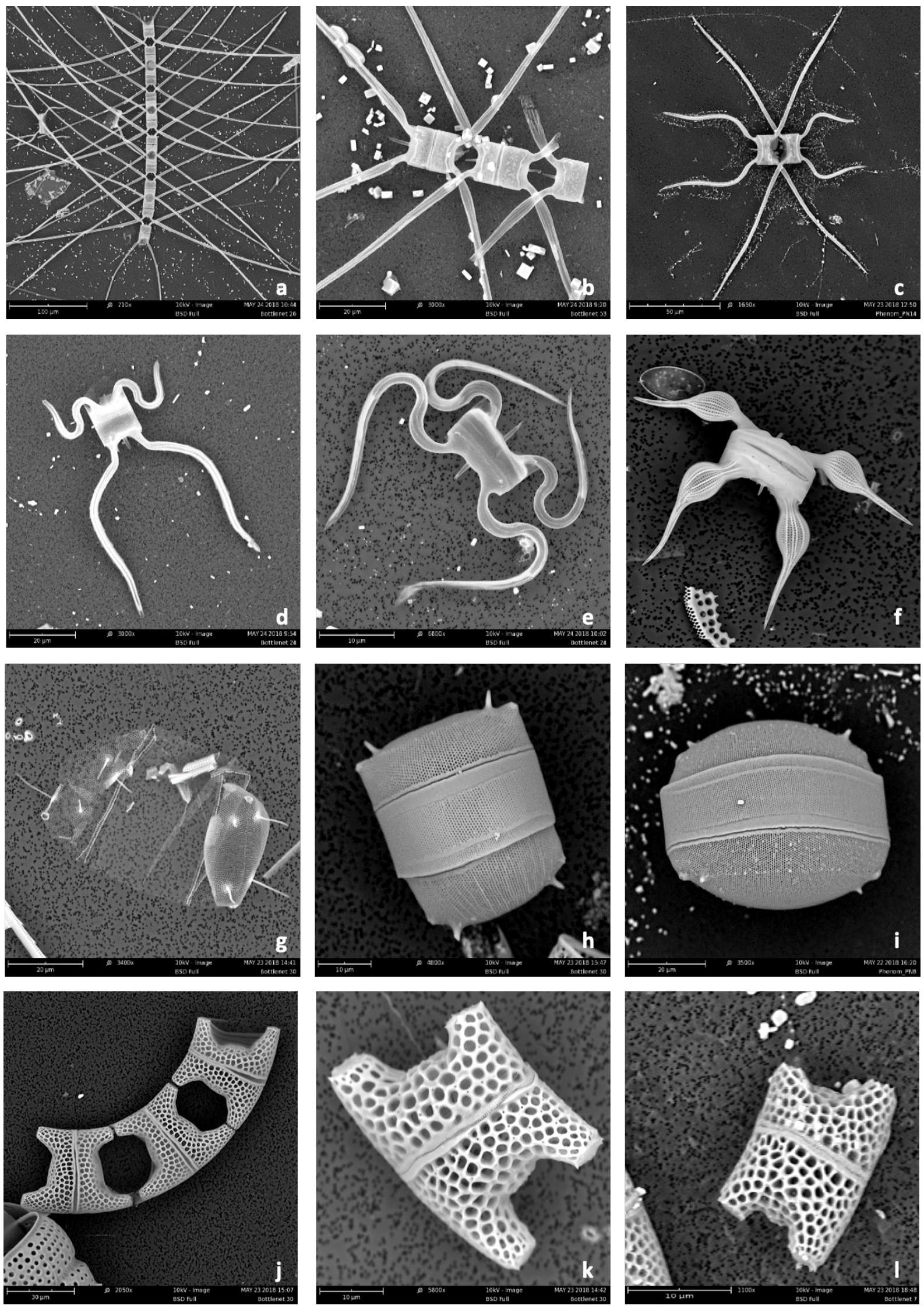

Suppl. Figure S3 : Morphological variations in two important species observed during the cruise. a to f. Chaetoceros atlanticus bulbosum complex. $\mathrm{G}$ to i: vegetative stage of Odontella weissflogii, rectangular resting cell/spore stage, round resting spore stage. $\mathrm{J}$ to I : Eucampia antarctica from vegetative colonial to small winter form. 

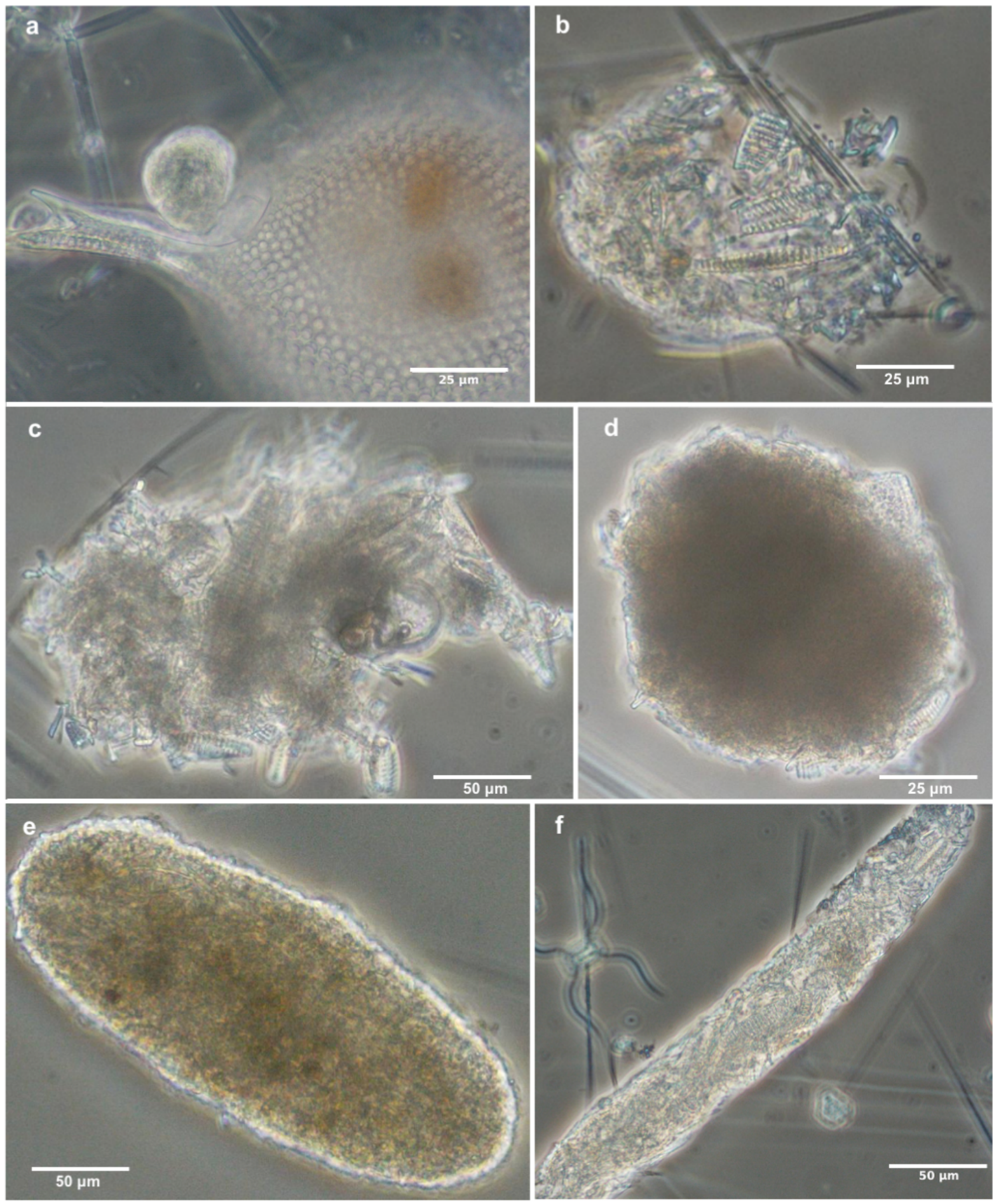

1037 Suppl. Figure S4: Different types of inert particles observed in the Bottle net samples. a) Minipellet $(<50 \mu \mathrm{m})$ produced by Protocystis spp., b) aggregates $<100 \mu \mathrm{m}, \mathrm{c})$ aggregates $100-400 \mu \mathrm{m}, \mathrm{d})$ spheroid fecal pellet, e) oval fecal pellet, f) cylindrical fecal pellet. 

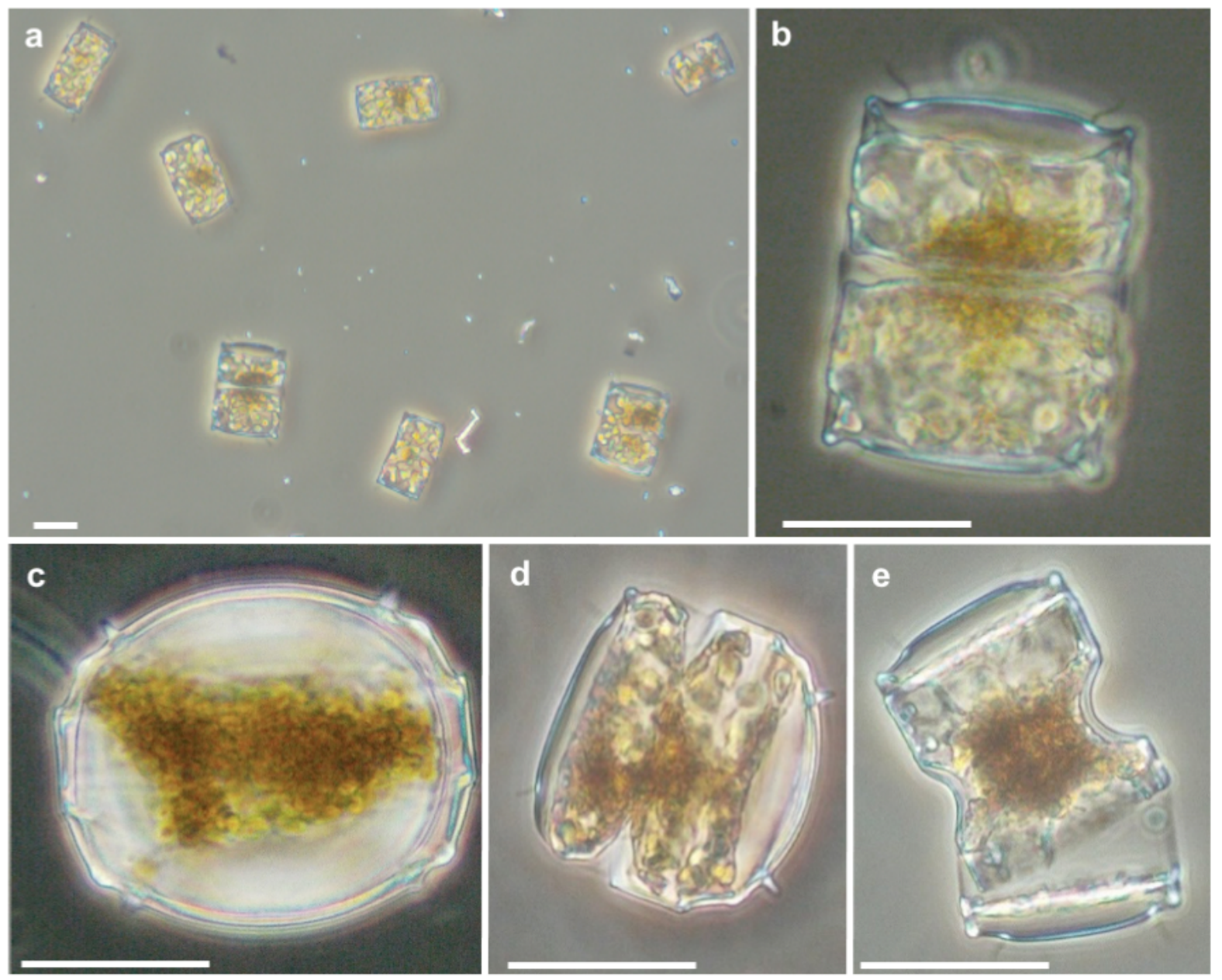

Suppl. Figure S5: Odontella weissflogii cells after 12 days incubation of resting cells in a light+Si+P treatment (a-b) and light only (c-e) treatment. Vegetative cells actively dividing (a-b), resting spore stage (c), half-vegetative half-spore like stage (d), abnormal valve due to the lack of Si (e). Scale bar: $25 \mu \mathrm{m}$. 


\section{References}

Agusti, S., Gonzalez-Gordillo, J.I., Vaque, D., Estrada, M., Cerezo, M.I., Salazar, G., Gasol, J.M., Duarte, C.M., 2015. Ubiquitous healthy diatoms in the deep sea confirm deep carbon injection by the biological pump. Nat Commun 6, 7608.

Agustí, S., Krause, J.W., Marquez, I.A., Wassmann, P., Kristiansen, S., Duarte, C.M., 2020. Arctic (Svalbard islands) active and exported diatom stocks and cell health status. Biogeosciences 17, 35-45.

Alldredge, A.L., Gotschalk, C.C., 1990. The Relative Contribution of Marine Snow of Different Origins to Biological Processes in Coastal Waters. Cont Shelf Res 10, 41-58.

Alldredge, A.L., Silver, M.W., 1988. Characteristics, Dynamics and Significance of Marine Snow. Prog Oceanogr 20, 41-82.

Armand, L.K., Cornet-Barthaux, V., Mosseri, J., Quéguiner, B., 2008a. Late summer diatom biomass and community structure on and around the naturally iron-fertilised Kerguelen Plateau in the Southern Ocean. Deep-Sea Research Part li-Topical Studies in Oceanography 55, 653-676.

Armand, L.K., Crosta, X., Queguiner, B., Mosseri, J., Garcia, N., 2008b. Diatoms preserved in surface sediments of the northeastern Kerguelen Plateau. Deep-Sea Research Part li-Topical Studies in Oceanography 55, 677-692.

Armand, L.K., Zielinski, U., 2001. Diatom species of the genus Rhizosolenia from Southern Ocean sediments: Distribution and taxonomic notes. Diatom Res 16, 259294.

Assmy, P., Henjes, J., Klaas, C., Smetacek, V., 2007. Mechanisms determining species dominance in a phytoplankton bloom induced by the iron fertilization experiment EisenEx in the Southern Ocean. Deep-Sea Res Pt I 54, 340-362.

Assmy, P., Smetacek, V., Montresor, M., Klaas, C., Henjes, J., Strass, V.H., Arrieta, J.M., Bathmann, U., Berg, G.M., Breitbarth, E., Cisewski, B., Friedrichs, L., Fuchs, N., Herndl, G.J., Jansen, S., Kragefsky, S., Latasa, M., Peeken, I., Rottgers, R., Scharek, R., Schuller, S.E., Steigenberger, S., Webb, A., Wolf-Gladrow, D., 2013. Thick-shelled, grazer-protected diatoms decouple ocean carbon and silicon cycles in the iron-limited Antarctic Circumpolar Current. Proceedings of the National Academy of Sciences of the United States of America 110, 20633-20638.

Biard, T., Krause, J.W., Stukel, M.R., Ohman, M.D., 2018. The Significance of giant Phaeodarians (Rhizaria) to Biogenic Silica Export in the California Current Ecosystem. Global Biogeochemical Cycles.

Blain S., Quéguiner B., Trull T.W., 2008. The natural iron fertilization experiment KEOPS (KErguelen Ocean and Plateau compared Study): An overview. Deep Sea Research Part II: Topical Studies in Oceanography, 55 (5-7), 559-565.

Blain, S., Rembauville, M., Crispi, O., Obernosterer, I., 2020. Synchronized autonomous sampling reveals coupled pulses of biomass and export of morphologically different diatoms in the Southern Ocean. Limnology and Oceanography.

Close, H.G., Shah, S.R., Ingalls, A.E., Diefendorf, A.F., Brodie, E.L., Hansman, R.L., Freeman, K.H., Aluwihare, L.I., Pearson, A., 2013. Export of submicron particulate 
organic matter to mesopelagic depth in an oligotrophic gyre. Proceedings of the National Academy of Sciences 110, 12565-12570.

Cornet-Barthaux, V., Armand, L., Queguiner, B., 2007. Biovolume and biomass estimates of key diatoms in the Southern Ocean. Aquat Microb Ecol 48, 295-308.

Crosta, X., Romero, O., Armand, L.K., Pichon, J.J., 2005. The biogeography of major diatom taxa in Southern Ocean sediments: 2. Open ocean related species. Palaeogeogr Palaeocl 223, 66-92.

Dall'Olmo, G., Mork, K.A., 2014. Carbon export by small particles in the Norwegian Sea. Geophys Res Lett 41, 2921-2927.

DiTullio, G., Grebmeier, J., Arrigo, K., Lizotte, M., Robinson, D., Leventer, A., Barry, J., VanWoert, M., Dunbar, R., 2000. Rapid and early export of Phaeocystis antarctica blooms in the Ross Sea, Antarctica. Nature 404, 595-598.

Durkin, C.A., Estapa, M.L., Buesseler, K.O., 2015. Observations of carbon export by small sinking particles in the upper mesopelagic. Mar Chem 175, 72-81.

Durkin, C.A., Koester, J.A., Bender, S.J., Armbrust, E.V., 2016. The evolution of silicon transporters in diatoms. J Phycol 52, 716-731.

Eppley, R.W., Reid, F.M.H., Strickland, J.D.H., 1970. The ecology of the plankton off La Jolla, California, in the period April through September, 1967. III. Estimates of phytoplankton crop, size, growth rate, and primary production. Bull. Scripps Inst. Oceanogr. 17, 33--42.

Fryxell, G.A., Prasad, A.K.S.K., 1990. Eucampia antarctica var. recta (Mangin) stat. nov. (Biddulphiaceae, Bacillariophyceae): life stages at the Weddell Sea ice edge. Phycologia 29, 27-38.

Gardner, W.D., Chung, S.P., Richardson, M.J., Walsh, I.D., 1995. The oceanic mixedlayer pump. Deep Sea Research Part II: Topical Studies in Oceanography 42, 757775.

Giering, S.L., Sanders, R., Lampitt, R.S., Anderson, T.R., Tamburini, C., Boutrif, M., Zubkov, M.V., Marsay, C.M., Henson, S.A., Saw, K., Cook, K., Mayor, D.J., 2014. Reconciliation of the carbon budget in the ocean's twilight zone. Nature 507, 480-483.

Gonzalez, H.E., 1992. Distribution and abundance of minipellets around the Antarctic peninsula. Implications for protistan feeding behaviour. Mar Ecol Prog Ser 90, 223223.

Gowing, M.M., 1986. Trophic biology of phaeodarian radiolarians and flux of living radiolarians in the upper $2000 \mathrm{~m}$ of the North Pacific central gyre. Deep Sea Research Part A. Oceanographic Research Papers 33, 655-674.

Gowing, M.M., 1989. Abundance and feeding ecology of Antarctic phaeodarian radiolarians. Mar Biol 103, 107-118.

Gowing, M.M., Silver, M.W., 1985. Minipellets: a new and abundant size class of marine fecal pellets. J Mar Res 43, 395-418.

Greenspan, P., 1985. Nile red: a selective fluorescent stain for intracellular lipid droplets. The Journal of Cell Biology 100, 965-973. 
Gutiérrez, M.H., Jara, A.M., Pantoja, S., 2016. Fungal parasites infect marine diatoms in the upwelling ecosystem of the Humboldt current system off central Chile. Environmental Microbiology 18, 1646-1653.

Gutierrez-Rodriguez, A., Stukel, M.R., dos Santos, A.L., Biard, T., Scharek, R., Vaulot, D., Landry, M.R., Not, F., 2019. High contribution of Rhizaria (Radiolaria) to vertical export in the California Current Ecosystem revealed by DNA metabarcoding. The ISME journal 13, 964-976.

Hamm, C.E., Merkel, R., Springer, O., Jurkojc, P., Maier, C., Prechtel, K., Smetacek, $\mathrm{V} .$, 2003. Architecture and material properties of diatom shells provide effective mechanical protection. Nature 421, 841-843.

Henson, S.A., Sanders, R., Madsen, E., Morris, P.J., Le Moigne, F., Quartly, G.D., 2011. A reduced estimate of the strength of the ocean's biological carbon pump. Geophys Res Lett 38.

Ikenoue, T., Kimoto, K., Okazaki, Y., Sato, M., Honda, M.C., Takahashi, K., Harada, N., Fujiki, T., 2019. Phaeodaria: An Important Carrier of Particulate Organic Carbon in the Mesopelagic Twilight Zone of the North Pacific Ocean. Global Biogeochemical Cycles 33, 1146-1160.

Iversen, M.H., Lampitt, R.S., 2020. Size does not matter after all: No evidence for a size-sinking relationship for marine snow. Prog Oceanogr 189.

Jacques G., 1983. Some ecophysiological aspects of the Antarctic phytoplankton. Polar Biology, 2, 27-33.

Kemp, A.E.S., Pike, J., Pearce, R.B., Lange, C.B., 2000. The "Fall dump"- a new perspective on the role of a "shade flora" in the annual cycle of diatom production and export flux. Deep Sea Research Part II: Topical Studies in Oceanography 47, 21292154.

Klaas C., Archer D.E., 2002. Association of sinking organic matter with various types of mineral ballast in the deep sea: Implications for the rain ratio. Global Biogeochemical Cycles, 16 (4), 63-61 - 63-14.

Kranzler, C.F., Krause, J.W., Brzezinski, M.A., Edwards, B.R., Biggs, W.P., Maniscalco, M., McCrow, J.P., Van Mooy, B.A., Bidle, K.D., Allen, A.E., 2019. Silicon limitation facilitates virus infection and mortality of marine diatoms. Nature microbiology, 1-8.

Laber, C.P., Hunter, J.E., Carvalho, F., Collins, J.R., Hunter, E.J., Schieler, B.M., Boss, E., More, K., Frada, M., Thamatrakoln, K., Brown, C.M., Haramaty, L., Ossolinski, J., Fredricks, H., Nissimov, J.I., Vandzura, R., Sheyn, U., Lehahn, Y., Chant, R.J., Martins, A.M., Coolen, M.J.L., Vardi, A., DiTullio, G.R., Van Mooy, B.A.S., Bidle, K.D., 2018. Coccolithovirus facilitation of carbon export in the North Atlantic. Nat Microbiol 3, 537547.

Lafond, A., Leblanc, K., Legras, J., Cornet, V., Quéguiner, B., 2020. The structure of diatom communities constrains biogeochemical properties in surface waters of the Southern Ocean (Kerguelen Plateau). J Marine Syst, 103458.

Lam, P.J., Marchal, O., 2015. Insights into particle cycling from thorium and particle data. Annual review of marine science 7, 159-184. 
Lampitt, R.S., Salter, I., Johns, D., 2009. Radiolaria: Major exporters of organic carbon to the deep ocean. Global Biogeochemical Cycles 23, GB1010.

Lasbleiz, M., Leblanc, K., Armand, L.K., Christaki, U., Georges, C., Obernosterer, I., Quéguiner, B., King, G., 2016. Composition of diatom communities and their contribution to plankton biomass in the naturally iron-fertilized region of Kerguelen in the Southern Ocean. FEMS microbiology ecology 92, 653--676.

Lasbleiz, M., Leblanc, K., Blain, S., Ras, J., Cornet-Barthaux, V., Hélias Nunige, S., Quéguiner, B., 2014. Pigments, elemental composition ( $C, N, P$, and Si), and stoichiometry of particulate matter in the naturally iron fertilized region of Kerguelen in the Southern Ocean. Biogeosciences 11, 5931-5955.

Laurenceau-Cornec, E.C., Trull, T.W., Davies, D.M., Bray, S.G., Doran, J., Planchon, F., Carlotti, F., Jouandet, M.P., Cavagna, A.J., Waite, A.M., Blain, S., 2015. The relative importance of phytoplankton aggregates and zooplankton fecal pellets to carbon export: insights from free-drifting sediment trap deployments in naturally ironfertilised waters near the Kerguelen Plateau. Biogeosciences 12, 1007-1027.

Laurenceau-Cornec, E.C., Le Moigne, F.A., Gallinari, M., Moriceau, B., Toullec, J., Iversen, M.H., Engel, A., De La Rocha, C.L., 2020. New guidelines for the application of Stokes' models to the sinking velocity of marine aggregates. Limnology and Oceanography 65, 1264-1285.

Laws, E.A., Landry, M.R., Barber, R.T., Campbell, L., Dickson, M.-L., Marra, J., 2000. Carbon cycling in primary production bottle incubations: inferences from grazing experiments and photosynthetic studies using and in the Arabian Sea. Deep Sea Research Part II: Topical Studies in Oceanography 47, 1339-1352.

Le Moigne, F.A.C., 2019. Pathways of Organic Carbon Downward Transport by the Oceanic Biological Carbon Pump. Frontiers in Marine Science 6.

Leblanc, K., Queguiner, B., Diaz, F., Cornet, V., Michel-Rodriguez, M., Durrieu de Madron, X., Bowler, C., Malviya, S., Thyssen, M., Gregori, G., Rembauville, M., Grosso, O., Poulain, J., de Vargas, C., Pujo-Pay, M., Conan, P., 2018. Nanoplanktonic diatoms are globally overlooked but play a role in spring blooms and carbon export. Nat Commun 9, 953.

Lundsgaard, C., 1994. Use of high viscosity medium in studies of aggregates, Sediment Trap Studies in the Nordic Countries. Symposium Proc., Mar. Biol. Lab., Helsingør, Denmark, pp. 141-152.

McDonnell, A.M., Lam, P.J., Lamborg, C.H., Buesseler, K.O., Sanders, R., Riley, J.S., Marsay, C., Smith, H.E., Sargent, E.C., Lampitt, R.S., 2015. The oceanographic toolbox for the collection of sinking and suspended marine particles. Prog Oceanogr $133,17-31$.

McQuoid, M.R., Hobson, L.A., 1996. Diatom Resting Stages. J Phycol 32, 889-902.

Mosseri, J., Quéguiner, B., Armand, L., Cornet-Barthaux, V., 2008. Impact of iron on silicon utilization by diatoms in the Southern Ocean: A case study of Si/N cycle decoupling in a naturally iron-enriched area. Deep Sea Research Part II: Topical Studies in Oceanography 55, 801-819.

Nakamura, Y., Suzuki, N., 2015. Phaeodaria: diverse marine cercozoans of world-wide distribution, Marine Protists. Springer, pp. 223-249. 
Omand, M.M., D’Asaro, E.A., Lee, C.M., Perry, M.J., Briggs, N., Cetinić, I., Mahadevan, A., 2015. Eddy-driven subduction exports particulate organic carbon from the spring bloom. Science 348, 222-225.

Park, Y.H., Durand, I., Kestenare, E., Rougier, G., Zhou, M., d'Ovidio, F., Cotté, C., Lee, J.H., 2014. Polar Front around the Kerguelen Islands: An up-to-date determination and associated circulation of surface/subsurface waters. Journal of Geophysical Research: Oceans 119, 6575-6592.

Pauthenet, E., Roquet, F., Madec, G., Guinet, C., Hindell, M., McMahon, C.R., Harcourt, R., Nerini, D., 2018. Seasonal Meandering of the Polar Front Upstream of the Kerguelen Plateau. Geophys Res Lett 45, 9774-9781.

Pelusi, A., De Luca, P., Manfellotto, F., Thamatrakoln, K., Bidle, K.D., Montresor, M., 2020. Virus-induced spore formation as a defense mechanism in marine diatoms. New Phytol.

Priddle, J., Fryxell, G., 1985. Handbook of the common plankton diatoms of the Southern Ocean. British Antarctic Survey.

Puigcorbé V., Masqué P., Le Moigne F.A.C., 2020. Global database of ratios of particulate organic carbon to thorium-234 in the ocean: improving estimates of the biological carbon pump. Earth System Science Data, 12 (2), 1267-1285.

Quéguiner, B., 2013. Iron fertilization and the structure of planktonic communities in high nutrient regions of the Southern Ocean. Deep Sea Research Part II: Topical Studies in Oceanography 90, 43-54.

Ragueneau, O., Savoye, N., Del Amo, Y., Cotten, J., Tardiveau, B., Leynaert, A., 2005. A new method for the measurement of biogenic silica in suspended matter of coastal waters: using Si:Al ratios to correct for the mineral interference. Cont Shelf Res 25, 697-710.

Rembauville, M., Blain, S., Armand, L., Quéguiner, B., Salter, I., 2015. Export fluxes in a naturally iron-fertilized area of the Southern Ocean - Part 2: Importance of diatom resting spores and faecal pellets for export. Biogeosciences 12, 3171-3195.

Rembauville, M., Manno, C., Tarling, G.A., Blain, S., Salter, I., 2016. Strong contribution of diatom resting spores to deep-sea carbon transfer in naturally ironfertilized waters downstream of South Georgia. Deep Sea Research Part I: Oceanographic Research Papers 115, 22-35.

Riaux-Gobin, C., Hargraves, P.E., Neveux, J., Oriol, L., Vétion, G., 1997. Microphyte pigments and resting spores at the water-sediment interface in the Subantarctic deep sea (Indian sector of the Southern Ocean). Deep Sea Research Part II: Topical Studies in Oceanography 44, 1033-1051.

Riaux-Gobin, C., Fontugne, M., Jensen, K.G., Bentaleb, I., Cauwet, G., ChrétiennotDinet, M.J., Poisson, A., 2006. Surficial deep-sea sediments across the polar frontal system (Southern Ocean, Indian sector): Particulate carbon content and microphyte signatures. Mar Geol 230, 147-159.

Richardson, T.L., Jackson, G.A., 2007. Small phytoplankton and carbon export from the surface ocean. Science $315,838-840$. 
Riemann, F., 1989. Gelatinous phytoplankton detritus aggregates on the Atlantic deepsea bed. Mar Biol 100, 533-539.

Rigual-Hernández, A.S., Trull, T.W., Bray, S.G., Armand, L.K., 2016. The fate of diatom valves in the Subantarctic and Polar Frontal Zones of the Southern Ocean: Sediment trap versus surface sediment assemblages. Palaeogeography, Palaeoclimatology, Palaeoecology 457, 129-143.

Rigual-Hernández, A.S., Trull, T.W., Bray, S.G., Closset, I., Armand, L.K., 2015. Seasonal dynamics in diatom and particulate export fluxes to the deep sea in the Australian sector of the southern Antarctic Zone. J Marine Syst 142, 62-74.

Riley, J., Sanders, R., Marsay, C., Le Moigne, F.A., Achterberg, E.P., Poulton, A.J., 2012. The relative contribution of fast and slow sinking particles to ocean carbon export. Global Biogeochemical Cycles 26.

Romero, O.E., Fischer, G., 2017. Shift in the species composition of the diatom community in the eutrophic Mauritanian coastal upwelling: Results from a multi-year sediment trap experiment (2003-2010). Prog Oceanogr 159, 31-44.

Salter, I., Kemp, A.E.S., Moore, C.M., Lampitt, R.S., Wolff, G.A., Holtvoeth, J., 2012. Diatom resting spore ecology drives enhanced carbon export from a naturally ironfertilized bloom in the Southern Ocean. Global Biogeochemical Cycles 26, n/a-n/a.

Salter, I., Lampitt, R.S., Sanders, R., Poulton, A., Kemp, A.E.S., Boorman, B., Saw, K., Pearce, R., 2007. Estimating carbon, silica and diatom export from a naturally fertilised phytoplankton bloom in the Southern Ocean using PELAGRA: A novel drifting sediment trap. Deep Sea Research Part II: Topical Studies in Oceanography 54, 22332259.

Sassenhagen, I., Irion, S., Jardillier, L., Moreira, D., Christaki, U., 2020. Protist Interactions and Community Structure During Early Autumn in the Kerguelen Region (Southern Ocean). Protist 171, 125709.

Scholz, B., Guillou, L., Marano, A.V., Neuhauser, S., Sullivan, B.K., Karsten, U., Kupper, F.C., Gleason, F.H., 2016. Zoosporic parasites infecting marine diatoms - A black box that needs to be opened. Fungal Ecol 19, 59-76.

Scott, F.J., Marchant, H.J., 2005. Antarctic marine protists. Australian Biological Resources Study Canberra.

Shukla, S.K., Crespin, J., Crosta, X., 2016. Thalassiosira lentiginosa size variation and associated biogenic silica burial in the Southern Ocean over the last $42 \mathrm{kyrs}$. Marine Micropaleontology 127, 74-85.

Smayda, T.J., 1978. From phytoplankton to biomass. 6. Phytoplankton manual.

Smith, H.E., 2014. The contribution of mineralising phytoplankton to the biological carbon pump in high latitudes. University of Southampton.

Stemmann, L., Jackson, G.A., Gorsky, G., 2004. A vertical model of particle size distributions and fluxes in the midwater column that includes biological and physical processes-Part II: application to a three year survey in the NW Mediterranean Sea. Deep Sea Research Part I: Oceanographic Research Papers 51, 885-908. 
Stukel, M.R., Biard, T., Krause, J., Ohman, M.D., 2018. Large Phaeodaria in the twilight zone: Their role in the carbon cycle. Limnology and Oceanography 63, 257913022594.

1303 Turner, J.T., 2002. Zooplankton fecal pellets, marine snow and sinking phytoplankton 1304 blooms. Aquat Microb Ecol 27, 57-102.

1305 Veldhuis, M., Kraay, G., Timmermans, K., 2001. Cell death in phytoplankton: 1306 correlation between changes in membrane permeability, photosynthetic activity, 1307 pigmentation and growth. Eur J Phycol 36, 167-177.

1308 Waite, A.M., Safi, K.A., Hall, J.A., Nodder, S.D., 2000. Mass sedimentation of 1309 picoplankton embedded in organic aggregates. Limnology and Oceanography 45, 87131097. 